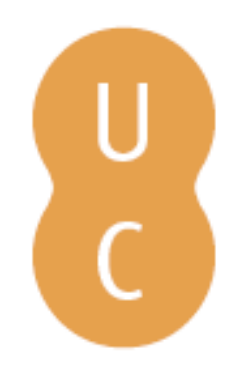

\title{
nommalina
}

\section{Philogelos (O Gracejador)}

\author{
Autor(es): Hiérocles, Filágrio \\ Publicado por: Imprensa da Universidade de Coimbra \\ URL \\ persistente: URI:http://hdl.handle.net/10316.2/29854 \\ DOI: $\quad$ DOI:http://dx.doi.org/10.14195/978-989-721-048-8
}

Accessed : $\quad$ 26-Apr-2023 12:22:02

A navegação consulta e descarregamento dos títulos inseridos nas Bibliotecas Digitais UC Digitalis, UC Pombalina e UC Impactum, pressupõem a aceitação plena e sem reservas dos Termos e Condições de Uso destas Bibliotecas Digitais, disponíveis em https://digitalis.uc.pt/pt-pt/termos.

Conforme exposto nos referidos Termos e Condições de Uso, o descarregamento de títulos de acesso restrito requer uma licença válida de autorização devendo o utilizador aceder ao(s) documento(s) a partir de um endereço de IP da instituição detentora da supramencionada licença.

Ao utilizador é apenas permitido o descarregamento para uso pessoal, pelo que o emprego do(s) título(s) descarregado(s) para outro fim, designadamente comercial, carece de autorização do respetivo autor ou editor da obra.

Na medida em que todas as obras da UC Digitalis se encontram protegidas pelo Código do Direito de Autor e Direitos Conexos e demais legislação aplicável, toda a cópia, parcial ou total, deste documento, nos casos em que é legalmente admitida, deverá conter ou fazer-se acompanhar por este aviso.

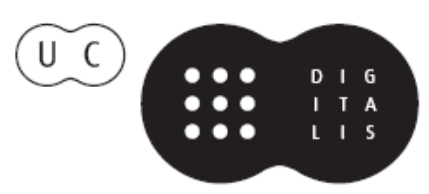




\section{Hiérocles e Filágrio}

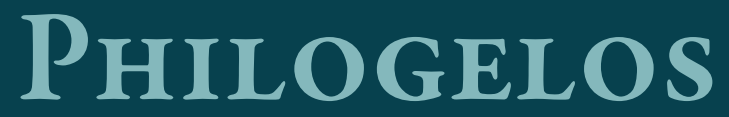

(O GRACEJADOR)

TRADUÇÃO DO GREGO, INTRODUÇÃO E NOTAS Reina Marisol Troca Pereira 



\section{Hiérocles e Filágrio}

\section{Philogelos (O Gracejador)}

TraduÇão do GREgo, INTROdUÇÃo E NOTAS

Reina Marisol Troca Pereira

Universidade de Coimbra

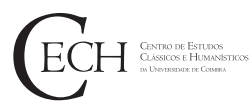


Todos os volumes desta série são sujeitos a arbitragem científica independente.

Autor: Hiérocles e FiLÁGrio

Título: Philogelos (O GRACEJADOR)

Traduçấo do grego, introduçấo e notas: Reina Marisol Troca Pereira

Editor: Centro de Estudos Clássicos e Humanísticos

EDIÇÃO: 1a/2013

Coordenador Científico do Plano de Edição: Maria do Céu Fialho

Conselho editorial: José Ribeiro Ferreira, Maria de Fátima Silva,

Francisco de Oliveira, Nair Castro Soares

Director técnico da colecção: Delfim F. Leấo

Concepção gráfica e paginaçāo: Rodolfo Lopes, Nelson Ferreira

Infografia: Mickael SiLVA

Obra REALIZADA No ÂMbito DAS ACTIVIDADES DA UI\&D

Centro de Estudos Clássicos e Humanísticos

Universidade De CoImbra

FACULDADE DE LeTRAS

TeL.: 239859981 | FAX: 239836733

3000-530 CoImbra

ISBN: 978-989-721-047-1

ISBN DigitAL: 978-989-721-048-8

Depósito Legal:368782/13

DOI: http://dx.doi.org/

10.14195/978-989-721-048-8

Obra Publicada com o Apoio de:

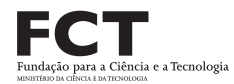

POCI $/ 2010$

(C) Classica Digitalia Vniversitatis Conimbrigensis (http://classicadigitalia.uc.pt)

(C) Centro de Estudos Clássicos e Humanísticos da Universidade de Coimbra

Reservados todos os direitos. Nos termos legais fica expressamente proibida a reprodução total ou parcial por qualquer meio, em papel ou em edição electrónica, sem autorização expressa dos titulares dos direitos. É desde já excepcionada a utilização em circuitos académicos fechados para apoio a leccionação ou extensão cultural por via de e-learning. 


\section{SUMÁrio}

Nota de Agradecimento

REFLEXÓES LIMINARES

INTRODUÇÃO 9

$\begin{array}{ll}\text { AbreViaturas } & 20\end{array}$

O Gracejador 21

Sobre Avarentos $\quad 46$

De abdera $\quad 47$

Sidónios $\quad 50$

Engraçadinhos $\quad 53$

Cidadãos de Cumas $\quad 56$

Mal-humorados $\quad 62$

Estúpidos $\quad 65$

$\begin{array}{ll}\text { Cobardes } & 67\end{array}$

Preguiçosos $\quad 68$

Invejosos 69

<cobardes> $\quad 69$

Glutôes $\quad 69$

Alcoólicos $\quad 71$

Sobre mulheres libertinas $\quad 75$

A respeito de homens misóginos $\quad 75$

$\begin{array}{ll}\text { A propósito de glutóes } & 78\end{array}$

$\begin{array}{lr}\text { BIBLIOGRAFIA } & 81\end{array}$

ÍNDICE TEMÁTICO 

Aos mestres do meu ser, Ventura e Idély, para todo sempre e mais ainda. Aos meus avós, Augusto Fernandes e Alice Pereira, infinda constância de ternos mementos, acre ausência.

A S. e F., de muitas alegrias e paciência infindas!

d.d.d. 


\section{Nota DE AGRADECIMENTO}

Não apenas pautaria pela injustiça, falta de verdade e hubrística imodéstia, deixar de reconhecer num tempo mais próximo, o labor incansável e a disponibilidade sempre presente em particular da Professora Doutora Maria do Céu Fialho, bem como dos Professores Doutores Delfim Leão e Frederico Lourenço, no encaminhamento, na avaliação e na edição da modesta tradução que ora se apresenta.

Outrossim, constituiria um imperdoável olvido passar sem mencionar o privilégio e a honra de partilhar tempo, espaço e saberes com todos os ilustres docentes que, de uma forma ou de outra, inspiraram o gosto pelas línguas, literaturas e culturas da Antiguidade Clássica.

Esperando, com a actual tradução, reflectir um pouco da mestria recebida e merecer perpetuar a obra e o(s) autor(es) em causa, ficam manifestos os devidos agradecimentos e o desejo de uma leitura aprazível.

Coimbra, 29 de Junho de 2013 


\section{INTRODUÇÃO}

'GRACEJADOR' ou 'Amante de Gracejos' corresponde à tradução da obra intitulada, na versão grega original, como $Ф \mathrm{\Lambda} О Г Е \Lambda \Omega \Sigma$. Trata-se da compilação de um conjunto de duzentos e sessenta e cinco pequenos apontamentos humorísticos, que circularam no período medieval.

De entre as fontes manuscritas sobreviventes, destacam-se algumas, distribuídas por diversos séculos, desde o (G) Cryptoferratensis A 33 (séc X/XI), ao (A) Par. sup. gr. 690 (séc. XI), ao (C) Vat. gr.112 (séc. XIV), aos (E) Estensis a P.7.16, (M) Monac. gr. 551, (P) Vat. palat. gr. 146, (V) Vind. gr. 192, todos do século XV, e ainda o (z) Par. sup. gr. 491. Porém, o número de peças e a ordo facietarum nesses documentos diferem, apresentando-se o Codex A como o mais completo ${ }^{1}$. A versão que seguidamente se expóe corresponde a uma reunião das facetiae presentes nos vários manuscritos, com algumas correcçóes, tal como disponibiliza R. Dawe

${ }^{1}$ Eberhard 186958 considera, na sua commentatio critica, a fonte mais extensa, com as 258 facetiae reunidas, um apógrafo devido a Minoides Minas, que descreve de modo assaz pejorativo, como uma pessoa desprovida de todo o sentido ético de respeito pelo material desconhecido de bibliotecas gregas e asiáticas, que roubava, escondia, destruía; e incapaz de empreender uma investigação séria: Minoides Minas, homo Graecus tot libris inuentis corruptis ablatis subditis celeber, publice Graeciae et Asiae bibliothecas perscrutatas ex codice aliquo descripserat, de quo quae scitu opus erant omnia omnes celauit. 
ed. (2000), Philogelos. Monachi et Lipsiae, Bibliotheca Scriptorum Graecorum et Romanorum Teubneriana.

A autoria da obra não reúne consenso, apesar de diversos manuscritos precederem o texto com seguinte indicação preliminar aparentemente esclarecedora:

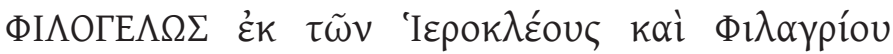

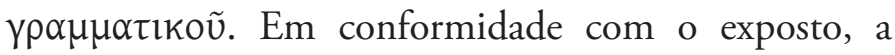
obra resultava de um trabalho conjunto, resta saber se de produção ou de edição, por parte de Hiérocles e Filágrio, já que a dupla autoria não era vulgar ${ }^{2}$. Apesar de o Codex V apenas denotar um autor, A e M criam a eventualidade de terem existido duas obras de dois compositores distintos, pertencendo a maior parte do material a Hiérocles. Posteriormente, houvera lugar a uma junção, de forma a constituir um exemplar único. Embora plausível, tal hipótese falha quer pela carência dos pretensos originais, quer pelo desconhecimento da identidade do compilador, provável criador do título. Contudo, explicar-se-ia, de modo plausível, a repetição, na mesma obra, de diversas facetiae (e.g. 2/175 bis, 10/157), mas apenas duplamente, donde se deduz, a

${ }^{2}$ Com efeito, um exemplo paradigmático no panorama literário da Antiguidade Clássica respeita a Historia Augusta, alegadamente da autoria conjunta de seis autores. Todavia, o notório esforço por manter o anonimato e a data de produção conduziram à constatação de que se tratava, na realidade, de um embuste literário. Comportava factos históricos, assentes em seis fontes essenciais, designadamente Mário Máximo, Herodiano, Dexipo, Eunápio e dois outros cuja identidade não reúne consenso. Juntava, outrossim, aspectos ficcionados acerca de biografias imperiais e de governantes, desde Hadriano a Carino, num total de trinta, compreendidas entre Diocleciano e Constantino I, provavelmente da autoria de um único agente, em Roma, c. 395 d.C.. Vd. Syme 1983; Ballou 1914. 
crer nessa premissa, tratar-se tão só de dois autores, duas obras e não mais.

Hiérocles e Filágrio mostram-se como duas personalidades algo obscuras. Identifica-se, frequentemente, o primeiro com sendo um neoplatónico de Alexandria, de meados do século V. Uma das suas obras, reconhecida como 'A $\mathrm{\alpha} \varepsilon \tilde{\imath} \alpha$, encontrada num manuscrito do século $\mathrm{X}$, apensa a um comentário da sua lavra sobre Pitágoras, compreendia 28 piadas. Teria o seu nome também associado a uma colectânea de textos humorísticos certamente criados, sob o seu nome, por um outro autor, em data posterior, pois a primeira edição conhecida remonta a 1605, devendo-se a Marq. Freherus, Ladenburg (cf. J. A. Schier, Leipzig, 1750).

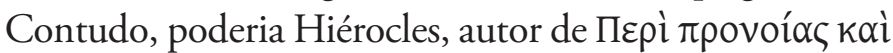

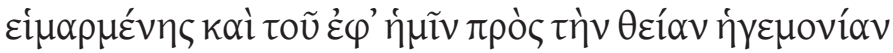

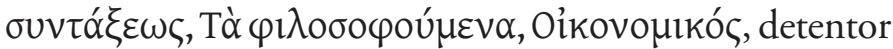
de um elaborado discurso erudito a propósito da filosofia pitagórica, tratar-se do mesmo indivíduo que arrolou umas tantas piadas pobres de conteúdo e parcas sob o ponto de vista da elaboração discursiva ${ }^{3}$; ou tão só uma coincidência de antropónimos - eis a dúvida irresoluta, já que não explica o acompanhamento de uma obra, cujo valor justifica a edição, com tradução latina, por J. Aurispa, Padua, 1474; e a reedição do original grego em 1583, por J. Curterius, Paris (cf. R. Warren, London,

${ }^{3}$ Needham 1709459 afirma-se como um crítico resistente face à atribuição de temáticas tão frívolas, numa forma de expressão tão despreocupada, a Hiérocles de Alexandria, não obstante a existência de autores do mesmo século que náo hesitavam divagar a respeito das facécias de Hiérocles. Vd. Johnson 1741 477-479. 
1742). Ademais, pese embora a dúvida instaurada, tal não obstaria a publicação de Hiérocles, com fragmentos e o adito humorístico, por J. Pearson, London, 1654; P. Needham, Cambridge, 1709; ou ainda J. de Rhoer's Observations Philologieae, Groningen, 1768. Para agudizar a situação, outra hipótese considera Hiérocles filósofo estóico, do século I, contemporâneo de Epicteto ${ }^{4}$.

Náo bastante, quanto ao segundo autor de Philogelos, quedam, outrossim, grandes incertezas, se considerada a versão que reporta a existência de um tal Filágrio, enquanto médico, posterior a Galeno (vd. Suid. 3 p.597), circunstância quiçá útil para as várias facécias relacionadas com doenças ou distúrbios físicos ou talvez para tanto bastassem influências de outras vias, como Heródoto. Ainda assim, provavelmente a figura de Filágrio se reportasse a um autor de mimos ${ }^{5}$, uma das fontes de Philogelos, do tempo de Augusto, também senhor de uma obra sob o mesmo título ${ }^{6}$. Não confundir, pois, com um sofista, segundo menciona, num apontamento de toda afirma inconclusivo, Filóstrato (VS. 578), quiçá o mesmo comediógrafo ${ }^{7}$ da época de Augusto, contemplado em

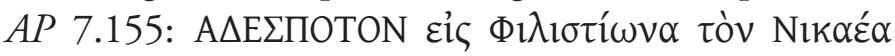

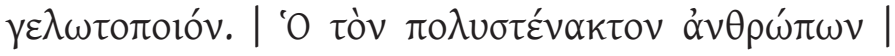

${ }^{4}$ Vd. Praechter 1901; Arnim - Schubart 1906.

${ }^{5}$ Vd. Reich 1903 454, acompanhando a discussão a propósito da autoria.

${ }^{6} \mathrm{Vd}$. Baldwin 1983 IV-XII esp.V-VI.

${ }^{7}$ Embora subsista um fragmento (fr. $1383 \mathrm{~K}$ ) relativo à Comédia Ática, no qual se verifica uma conversaçáo entre Menandro e Filístion, deve entender-se este último nome como uma confusão com Filémon, já que nem sequer partilhavam contemporaneidade. Vd. Edmonds 1957 511. Cf. Cornford 2011. 


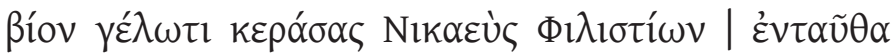

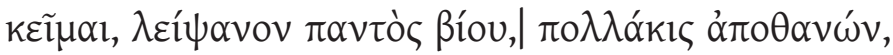

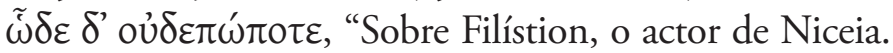
Eu, Filístion de Niceia, que temperou com riso a miserável vida dos homens, jazo aqui, para o resto de toda a vida. Foi meu hábito morrer, mas nunca desta forma". Um esclarecimento mais cabal e condicente com a introdução da obra surge por intermédio da fonte Suda (3 p.603), ao afirmar que, no tempo de Sócrates ${ }^{8}$, teria falecido Filístion, autor de várias obras, entre as quais Philogelos. De resto, apenas a alusão inexistente na maioria dos códices, mas grafada no Cod. M - Monac. gr. 551, que reporta Filístion como gramático.

Outrossim, a datação da obra continua envolta em controvérsia. Com efeito, as referências diacrónicas presentes nos textos encontram-se repartidas, não permitindo estabelecer uma ligação certa com o(s) seu(s) autor(es $)^{9}$. Ademais, outras informaçóes constantes no texto não possibilitam também uma datação contundente - quiçá entre os séculos III e VI da Era Cristá. Notem-se, a título de exemplo, aspectos como os jogos do milénio (facetia 62), o que indicaria o evento promovido em 248; o Serapeum em Alexandria (76), porventura antes da destruição do templo, em 391; ou supostamente a sugestão das leis romanas reguladoras do tráfego (138), introduzidas por Júlio César; o uso regular de calças no vestuário, até ao século II tido como um sinal de barbárie,

${ }^{8}$ Cf. Smith 1580295 reporta a informaçấo disponibilizada por Suídas, respeitante à morte de Filistion no tempo de Sócrates, como um erro.

${ }^{9} \mathrm{Vd}$ a ténue alusão a Alexandria, apenas nas facécias 76 e 171. 
mas, nos séculos IV/V, vulgarizado $(64)^{10}$; o cursus

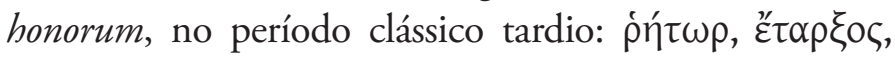

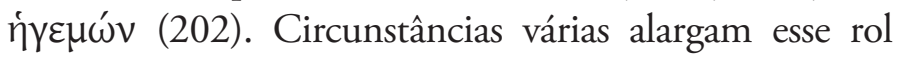
de ligaçóes à realidade, como a alusão a um horóscopo elaborado por um profeta, longe já da inspiração mântica ou do estado de enthousiasmos das profetisas do cenário pagão (202); a alusão a gladiadores (e.g. 87, 216); a protecção romana face à cegueira enquanto castigo (138); factos relacionados com a actividade teatral (226, 239); a referência a festivais atléticos (144); a denotação de vectores como a venda de livros usados (20); o pugilismo (e.g. 172); a navegação ${ }^{11}$; as viagens Rodes-Sicília (192); o Rio Reno (83); Alexandria $(76,171)$. Porém, nenhuma das notas por si só determina que se situe a obra num momento anterior ao século IV, já que as alusóes podem sempre emitir-se a posteriori dos eventos referidos. Assim se passa com alguns antropónimos, como Escribónia (73) ou Loliano (162), o primeiro parecendo sugerir a existência de um nexo augustano; e o segundo, a identificação com o sofista de Éfeso do séc. II, com o mesmo nome. Nem os lexemas $\Theta \varepsilon \varepsilon$ (AC) ou Kúpı (EV), "Deus/Senhor",

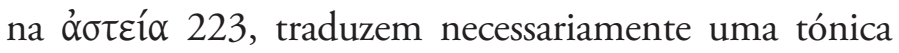
exclusiva do credo Judaico-Cristão, nem tampouco, no inverso, a asserção de que o humor se tenha limitado em exclusivo ao contexto pagão, conforme se constata, a título ilustrativo, numa tonalidade erudita, em Sócrates de Constantinopla (IV/V d.C.), Historia Ecclesiastica / Historia Ecclesiae 6.22, referente ao bispo Sisínio.

${ }^{10}$ Cf. Juv. 2.169. Vd. Constable — Kazdan 1982.

${ }^{11} \mathrm{Vd}$. Rougé 1987 3-12. 
Em termos formais, certo é o reconhecimento de um registo tardio, porquanto, embora haja traços manifestos de paganismo, se verifica a inserção de diversos bizantinismos, lexemas recorrentes na escrita patrística (e.g. 141: $\varphi \alpha ́ \beta \alpha ; 145: \tau \alpha \xi \varepsilon \omega ́ \tau \eta \eta)$, latinismos,

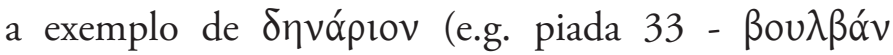
Cf. Lucil. AP 11.410; motejo 86. Cf. denarius, 135-

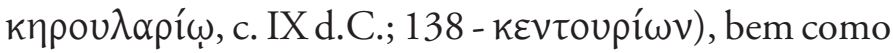

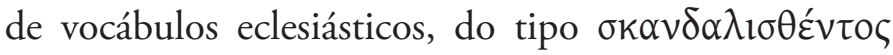
(e.g. $\sigma \kappa \alpha v \delta \alpha \lambda i \zeta \omega$, gracejo 44. Cf. N.T. Math. 11.6), num grego vernacular, o que denuncia uma maior aproximação a um registo oral, do que a uma versão escrita. O teor da obra não carecia de uma fraseologia mais requintada ou de construçóes mais elaboradas, filtradas por revisóes cuidadas, o que correspondia à conduta vulgarmente seguida por códices dos séculos IX/X. No geral, uma apreciação da obra na sua globalidade denota uma certa aptidáo do seu conteúdo para a teatralidade. Os textos premeiam pelo cariz curto, conciso, breve, rápido, sem despender tempo com introitos ou particularizaçóes supérfluas para a chegada ao essencial - o climax, tantas vezes adornado com o efeito do inesperado (cf. paraprosdokia).

$\mathrm{Na}$ realidade, o material apresentado tinha origens anteriores $^{12}$ às dos seus alegados autores. O humor surge como algo ingénito à raça humana, que influencia de forma mais ou menos consciente a obra Philogelos, como herdeira de um factor lúdico socialmente subversivo de

${ }^{12}$ Vd. Robert 1969 181-291, esp. 289 n.3, ao considerar o material anterior que teria sido aproveitado para a elaboração do Philogelos. 
continuidade. Com efeito, manifesta influência egípcia ${ }^{13}$; aparece de certo modo sugerido, desde a tradição da épica dita homérica ${ }^{14}$; e algumas piadas surgem enunciadas até nas obras de escritores latinos. Contrariamente ao retrato dos cidadáos romanos, envergando o sóbrio valor tradicional da grauitas, importa considerar o italum acetum, ingénito no povo do Lácio e presente em manifestaçóes, como a fescenina iocatio, os ludi osci, a satura ${ }^{15}$, o mimo (ludus graecus, fabula planipedaria), também elas manifestadas nas produçôes literárias, em particular cómicas e satíricas. Afinal, delectare constituía uma das três funçóes canónicas do discurso (cf. Cic. Or. 69). Notem-se, nesse sentido, de entre gregos e latinos, o helénico Xenofonte (An. 5.7.25. Cf. facetia 2); Aristófanes (166 - óvos/vóoc. Vd. Nu. 1273. Cf. Pl. Lg. 701c); Plauto (figura do alazon, Miles Gloriosus. Cf. 19 - Pl. Ax. 367b); Cícero (e.g. piadas 18, 193. Cf. Cic. De Or. 2. 274, 2.276, respectivamente); autores pré-Apuleio, como Veleio Patérculo (e.g. piada 78. Cf. Veleio Patérculo 1.13.14); o grego Plutarco (e.g. piadas 21, 148, 263, 264. Cf. Plu. Mor. 177 A, 255 E, 178 F, respectivamente), ou outros, em particular o músico ateniense Estratonico (IV a.C.); Luciano de Samósata; Ateneu (e.g. 352a - piada 24). Tal denuncia a existência de um gosto particular pelo humor, na Antiguidade, tanto grega, como latina, disperso em várias obras, ou condensado em produçóes exclusivamente votadas ao assunto, como o novo género - as trabeatae de Melisso, professor de Augusto (cf. Suet.

\footnotetext{
${ }^{13}$ Vd. Wilkinson - Birch 1878.

${ }^{14} \mathrm{Vd}$. Sikes 1940 121-127.

${ }^{15} \mathrm{Vd}$. Hendrickson 1927 42-60.
} 
Gram. 21: fecit et nouum genus togatarum inscripsitque trabeatas). Eis, pois, a referência, por parte de autores como Ateneu (614d-e); Macróbio (2.1.8-15); Plauto (Per. 392-395, St. 400, referente a escritos que os escravos utilizavam no entretenimento dos seus senhores), a colecçôes de anedotas.

Em termos estruturais, a obra reflecte um tipo de humor que parece resultar do processo de transição da Comédia Antiga para a Comédia Nova. Constata-se, assim, a ridicularização de figuras e (ou) situaçóes não individualizadas, particularizadas ou nomeadas, donde a organização das piadas do Philogelos por caracteres, motivos ou etnias: idiotas; avarentos; habitantes de Abdera; sidónios; engraçadinhos; habitantes de Cumas; mal-humorados; estúpidos; cobardes; preguiçosos; invejosos; glutôes; alcoólicos; pessoas com mau hálito; mulheres libertinas; morte; roubo; insónias; homens misóginos. Os segmentos recolhem números distintos de anedotas, cabendo ao grupo dos scholastichi a maior expressão, contrariamente ao expectável (ora parvo, ora inteligente, discordante; ora mais jovem; ora mais velho, experiente e cioso pela comprovação dos factos).

Constituem motivo de ridículo aspectos tão variados, como funerais; banhos públicos; viagens de barco; avareza; doentes e doenças; estudantes; glutôes; alcoólicos, entre outros. O pendor cómico, regra geral, prima pela simplicidade, embora o seu 'bom gosto' mediante os padrôes hodiernos seja em várias ocasióes discutível. Na realidade, no seu todo, apresenta-se um manancial, com as devidas reservas, informativo de 
hábitos e comportamentos sociais, em consideraçôes extremadas que denotavam o teor do ridículo e do risível à época, permitindo, de igual forma, uma leve (porque não bastante para se julgar um índice avaliativo) reflexão a propósito do humor e do modo como o material visado recebia tratamento. Neste ínterim, o distanciamento dos leitores/ouvintes da actualidade confronta-se com a perda de situaçóes quotidianas vulgares, ou hábitos reconhecidos a certos grupos profissionais ou categorias sociais $^{16}$, como professores, estudantes, pais/filhos (conflitos geracionais), médicos ${ }^{17}$; padeiros; barbeiros; astrólogos; juízes, advogados; governadores. Por vezes o humor assume tonalidades vitriólicas; negras; misóginas, embora sejam diminutas as piadas com mulheres (227, 244, 245); desprovidas de sympatheia no respeitante a doenças, o que não cativa momentos prazerosos e de lazer, mas antes de repulsa, revolta. Por conseguinte, algumas notas concernentes a liçóes a retirar do riso (Pl. $R$. 388c-389a) e ao refreamento aconselhável (Pl. $L g$. 935b-936c), como posteriormente fixariam os romanos - ridendo castigat mores. Ainda assim, em múltiplas ocasióes, a comicidade detém-se presentemente.

A existência de repetições de textos, praticamente totais, com pouquíssimas diferenças, todas elas assinaladas a seu tempo, na tradução, pode de igual modo reportar, não apenas o gosto particular por certas piadas, mas sobretudo o carácter transversal de

${ }^{16}$ Vd. Propp 1992 79-83; Bremmer — Roodenburg 1997. Cf. Sátira dos Ofícios, de Khéti, obra de origem egípcia, do segundo milénio a.C.

${ }^{17}$ Vd. Heraclit. fr. 58 Diels. Cf. Ribeiro Jr. 2006 224-233. 
determinados motivos, cuja funcionalidade podia aplicar-se em diversos contextos.

No conjunto, apresenta-se um material despretensioso, em termos de qualidade textual e de densidade semântica, mas ainda assim capaz de proporcionar agradáveis momentos de leitura. Embora de circulação abrangente no período medieval e da (re)utilização de certos topoi na literatura posterior, o interesse parece ter esvaecido mormente após a publicação de Eberhard, em 1869. Com efeito, quando Charles Clinch Bubb imprime The Jests of Hierocles and Philagrius, Cleveland, The Rowfant Club, em 1920, a tiragem não ultrapassou os 125 exemplares. Ainda assim, importa destacar que, fora quaisquer condicionantes político-sociais menos favoráveis, o humor acompanha a humanidade, marcando presença transversalmente ao longo do seu percurso. 


\section{Abreviaturas}

As abreviaturas usadas de autores e obras da Antiguidade Greco-Latina são as de H. Liddell — R. Scott (1992), A Greek-English Lexicon. New York, Oxford University Press, e P. Glare (1982), Oxford Latin Dictionary. New York, Oxford University Press.

As publicações periódicas são referidas pelas abreviaturas de L'Année Philologique. 


\section{O Gracejador}

DE Hiérocles E do GRAMÁtico FilÁGrio 

1. Um idiota pediu a um artesão que lhe fizesse uma lanterna.

- "Quão grande?”

- "Suficientemente grande para três pessoas".

2. Um tolo foi dar um mergulho e quase que se afogou. Em resultado disso, jurou que nunca mais voltaria a aproximar-se de água sem antes aprender a nadar.

3. Um indivíduo, ao consultar um médico idiota, fez a seguinte afirmação:

- "Doutor, sempre que me levanto depois de dormir, sinto-me zonzo durante uma meia hora, mas depois fico bem."

Ao que o médico respondeu:

- "Então espere meia hora antes de se levantar."

4. Alguém perguntou a um idiota que estava a vender um cavalo se ele já tinha perdido [a primeira dentição].

-"Sim, por acaso ele até já perdeu uma segunda."

- "Como é que sabe?”2

- "Porque ele já derrubou uma vez a mim e outra ao meu pai."

${ }^{1}$ Cf. 175 bis.

${ }^{2}$ Cf. 155. 
5. Ao deparar-se com um apatetado, um homem disse:

- "Douto senhor, eu já o vi nos meus sonhos."

- "Valham-me os deuses, respondeu ele, eu estava táo ocupado que nem dei por si!"

6. Ao ver que o médico estava a vir na sua direcção, um xexé procurou evitar ser visto por ele. Quando um amigo lhe perguntou a razáo, ele respondeu:

-"Porque já lá vai tanto tempo em que eu não estou doente, que fiquei constrangido em encontrar o doutor."

7. Um médico tinha proibido de falar um idiota a quem tinha operado a úvula. Por tal, ordenou ao seu escravo que cumprimentasse por si quem o procurasse. Mas depois continuou a dizer a cada pessoa que o solicitava: "Náo se sinta ofendido por o meu escravo o ter cumprimentado por mim - é que o médico proibiume de falar."

8. Um tolo, tentando apanhar um rato que andava constantemente a roer os seus livros, sentou-se de guarda, no escuro, a mordiscar ruidosamente carne crua.

9. Um idiota tentou ensinar o seu burro a não comer tanto, não lhe dando alimento. Todavia, como o burro morresse, ele exclamou. "Que grande desgraça! 
Mal eu o tinha ensinado a não comer, dá-lhe para morrer!"

10. Um paspalho estava a vender um cavalo, quando lhe indagaram se ele tinha receio de alguma coisa. "Pela saudinha do meu pai, penso que não!", respondeu ele. "Na realidade, ele fica sozinho na estrebaria!"3

11. Pretendendo saber que aspecto tinha enquanto dormia, um imbecil pôs-se à frente de um espelho com os olhos fechados.

12. "Serias capaz de me comprar dois rapazes escravos de quinze anos?", perguntou o amigo de um idiota que estava a pensar viajar, ao que este respondeu: "Se eu não conseguir encontrar dois rapazes de quinze anos, compro-te um de trinta anos."

13. Dois patarocos estavam a queixar-se um ao outro que os seus pais, que eles detestavam, ainda se encontravam um deles sugeriu: "Bem, deverá cada um de nós apertar o pescoço aos nossos velhotes?”

- "Mas se fizermos isso seremos apontados como parricidas", assinalou o outro.

- "Eu tenho uma ideia melhor. Tu matas o meu e eu mato o teu."

${ }^{3}$ Cf. 157.

${ }^{4}$ Cf. 152 . 
14. Tendo comprado uma casa, um sandeu pôs-se à entrada a perguntar a quem passava se condizia consigo.

15. Tendo sonhado que tinha pisado um prego, um desmiolado resolveu pôr uma ligadura no pé. Explicou o porquê a um amigo, que indagou o que lhe tinha acontecido.

"Não admira que nos chamem parvos!", explicou o amigo. "O que é que te deu para dormires descalço?"

16. Um paspalhão passou muitos dias a procurar por um livro, sem sucesso. Então, quando calhou sentar-se a olhar para um canto enquanto comia alfaces, apercebeu-se lá do livro.

Mais tarde, encontrou-se com um amigo que estava muito preocupado por ter perdido um fato completo. "Não te preocupes", disse, "compra umas alfaces e olha para um canto enquanto estiveres a comêlas: encontrarás as tuas roupas!"

17. A um cabeça-de-vento que estava de viagem no Estrangeiro escreveu um amigo, para que ele lhe comprasse alguns livros.

Ele, contudo, esqueceu-se. Então, ao regressar, quando encontrou o dito amigo, explicou: "Nunca cheguei a receber a carta que me escreveste a propósito dos livros." ${ }^{\prime \prime}$

${ }^{5}$ Cf. 44 bis. 
18. Um indivíduo foi ao encontro de um idiota e reclamou: "Aquele escravo que me vendeste morreu!"

"Juro por todos os deuses - desculpou-se ele -, que ele nunca tinha feito tal coisa quando eu o tinha!"

19. Ao avistar um bando de pardais no cimo de uma árvore, um imbecil ajeitou o regaço e abanou a árvore para apanhar os pardais à medida que caíssem.

20. Depois de um jantar, dois paspalhos que estavam a procurar entrar em acordo sobre quem iria acompanhar o outro a casa, conforme as regras de etiqueta, acabaram por náo chegar a ir à cama.

21. Um idiota queria dormir, mas não tinha almofada, pelo que deu ordens a um escravo para lhe trazer um recipiente de cerâmica. Quando o escravo referiu que isso era duro, ele disse-lhe para enchê-lo de penas.

22. Certo dia, um néscio encontrou um amigo e comunicou-lhe: "Ouvi dizer que tinhas morrido."

Ele retorquiu: "Mas como vês, eu estou vivo".

- "Sim, mas quem me contou a respeito disso era muito mais confiável do que tu."

23. Ao entrar nos banhos públicos (termas) à hora de abertura e não encontrando lá viv'alma, um tolo comentou para o seu escravo: "Pelo que vejo, o banho 
não está a funcionar hoje ...” ${ }^{\prime 6}$

24. Um idiota, numa discussão com o seu pai, vociferou: "Não consegues perceber a safadice que me fizeste?! É que se tu não tivesses nascido, eu teria sido o herdeiro do meu avô!”

25. Um estúpido estava a fazer uma viagem marítima, quando despontou uma tempestade, provocando o pranto dos seus escravos. "Não se lamentem", consolou-os ele, "pois libertei-vos a todos no meu testamento".

26. Um mentecapto, que estava à procura do melhor local para construir o seu túmulo, questionou algumas pessoas. Quando the foi recomendado um determinado sítio, ele ripostou: "Mas essa zona é insalubre!"7

27. Um idiota que estava doente prometeu ao médico uma recompensa, caso o curasse. Mais tarde, quando a esposa estava a criticá-lo por beber vinho, mesmo tendo febre, ele respondeu: "Acaso queres que eu melhore e tenha que pagar ao médico a recompensa?"8

28. Um cão mordeu o polegar a um idiota. Ele
${ }^{6}$ Cf. 130 .
${ }^{7}$ Cf. 73.
${ }^{8}$ Cf. 79 bis. 
comentou: "Podia ter sido pior. Se ele tivesse mordido o meu manto, este estaria desfeito em pedaços."

29. Era uma vez dois irmãos. Um deles morreu. Ao encontrar o sobrevivente, um paspalho indagou: "Quem morreu, foste tu ou o teu irmão?"

30. Um idiota, estando a ponto de naufragar, solicitou umas tabuinhas para fazer o seu testamento. Mas vendo os escravos agitados por causa do perigo, afirmou: "Não se aflijam, pois libertei-vos a todos no meu testamento."

31. Pretendendo atravessar um rio, um idiota apanhou um barco montado no seu cavalo. Quando the perguntaram por que razão não tinha desmontado, ele respondeu: "Porque estou com pressa!"10

32. Tendo aceitado um convite para jantar, um idiota não estava a comer nada.

-"Porque é que não come?", interpelou um comensal.

-"Porque não quero que as pessoas pensem que vim pela comida." 11

33. O filho de um néscio estava a jogar à bola,

${ }^{9}$ Cf. 25.

${ }^{10}$ Cf. 91 bis.

${ }^{11}$ Cf. 96 bis. 
quando esta caiu dentro de um poço. Ao espreitar lá para dentro, o rapaz viu a sua sombra e pediu-lhe para devolver a sua bola. [Como tal náo aconteceu], queixou-se ao pai que não conseguia ter a sua bola de volta. Ele então espreitou para dentro do poço e, vendo a sua própria sombra, [pediu a bola]: "Senhor - declarou -, faça a gentileza de devolver a bola ao rapaz!”

34. Ao ir visitar um outro imbecil adoentado, um idiota perguntou-lhe como estava. Contudo, encontrando-se tomado pela febre, o doente não teve força para falar. Irritado, aquele vociferou ao sair: "Espero ficar doente um dia e então poderei não te responder!"

35. Um idiota comprou umas roupas roubadas e, para evitar que fossem descobertas, assinalou-as. ${ }^{12}$

36. Ao chegar, um tolo procurou saber o valor de umas roupas. Mas, em virtude de o seu pai ter ficado a saber por algumas pessoas das suas intençóes, ele disse-lhe: "Pai, - argumentou ele - estiveste a dar ouvidos às patranhas de uma fonte sem credibilidade!", ao que ele retorquiu: "Náo, não! Foi um Fulano que me contou."

- "E tu, disse ele, deste-lhe ouvidos - a um homem que tem uma roupa que não vale cinquenta dracmas?”

37. Um idiota tinha um cavalo para venda. A um

${ }^{12}$ Cf. 158. 
possível cliente que veio até si e o inquiriu acerca da sua dentição, ele disse: "Porque é que estás tão interessado a respeito dos dentes dele? Tomara eu que ele se movesse com a velocidade com que come!"13

38. Um idiota pediu aos seus amigos para trazerem ramos de flores para o funeral do seu pai, que estava doente. Por isso, ficaram aborrecidos quando no dia seguinte ele pareceu estar melhor. "Peço desculpa pela despesa desnecessária", afirmou o idiota, "mas tragam os ramos outra vez amanhã e eu enterro-o, esteja ele como estiver!"

39. Dois tansos iam a caminhar juntos, quando um deles avistou uma ave negra. "Irmão - referiu -, aposto em como o companheiro morreu e por isso se vestiu de negro!"

40. Quando se apercebeu da grande quantidade de condolentes que estava a chegar para o funeral do seu pequeno filho, em virtude de ser um homem de posses e com influência, um idiota balbuciou: "Sinto-me constrangido por estar a enterrar uma criança tão pequena diante de tão grande congregação.”

41. Tendo comprado uma casa, um idiota andava carregado com uma pedra retirada dela, para mostrar às

${ }^{13}$ Cf. 158 bis. 
pessoas como é que ela era. ${ }^{14}$

42. Indo dois idiotas a caminhar, um deles, por força do seu intestino, viu-se obrigado a retirar-se um pouco. Depois encontrou escrito no marco da estrada, pelo outro: "Apanha-me ..." 15

43. Um papalvo, ao ouvir de algumas pessoas que "A tua barba está prestes a aparecer", foi logo ao portão para lhe dar as boas vindas. Quando um outro indivíduo lhe perguntou o que é que ele estava a fazer ali, e lhe foi dito, ele afirmou: "Náo admira que nos chamem parvos! Tanto quanto sabes, ela pode estar a vir pelo outro portáo!”

44. Um idiota que estava a dormir com o seu pai levantou-se de noite e começou a comer as uvas que estavam sobre a sua cabeça. Mas, mal ele se levantou, o pai apontou-lhe uma lanterna que ele tinha escondido num vaso. Apanhado em flagrante, ele manteve-se imóvel e fingiu estar a dormir, roncando.

44 bis. Um amigo escreveu a um tolo que estava ausente no Estrangeiro, para que ele lhe conseguisse alguns livros.

Ele contudo negligenciou [o pedido]. Então, ao regressar, quando encontrou o amigo, explicou: "Nunca
${ }^{14}$ Cf. 156.
${ }^{15}$ Cf. 132. 
cheguei a receber a carta que me escreveste a propósito dos livros."

45. Um idiota, de noite, foi deitar-se com a sua avó. Quando o seu pai o repreendeu por isso, ele protestou "Mas tu tens estado a dormir com a minha mãe há anos e eu nunca te repreendi. Então porque é que tu estás aborrecido comigo, ao encontrares-me a dormir uma vez com a tua mãe?

46. Quando um comerciante comunicou a um néscio que o rio tinha invadido a sua propriedade, este deplorou e respondeu, comentando: "Violenta-nos."

47. Ao efectuar uma visita ao campo após uma longa ausência, um idiota viu as ovelhas a dirigir-se para o pasto, balindo como de costume. Quando perguntou por que motivo estavam a fazer aquele ruído, o pastor pensou pregar-lhe uma partida, respondendo: "Elas estão a louvar-te".

- "Como eu espero aproveitar um bocado, para meu bem, dá-lhes um descanso e não as faças ir para o pasto nos próximos três dias.”

48. Um idiota calçou uns sapatos novos, mas eles chiavam. Então ele deteve-se e disse: "Parem de chiar! Estão a desgastar as minhas pernas!"

49. Ao contemplar a lua, um simplório perguntou ao seu pai se as outras cidades tinham uma outra lua assim. 
50. Um idiota que era agiota disse a um capitão de navio que tinha uma dívida consigo, para lhe dar um caixão para si e dois caixóes pequenos para os seus filhos de oito anos, com o tamanho proporcional à importância em dívida.

51. Ao dar conta de um poço na sua propriedade, um palerma perguntou se a água era boa.

- "Sim, é boa”, responderam os agricultores vizinhos. "Na realidade, os teus pais costumavam beber daí."

-"E quão longos pescoços eram os seus, ao ponto de serem capazes de atingir o fundo de tamanha profundidade para beber?"

52. Um idiota caiu num buraco e chamou por ajuda. Como ninguém prestava atenção, ele pensou para si: "Diabos, se eu não trepo até lá e lhes bato até prestarem atenção e trazerem-me uma escada!"

53. Um palerma estava a jantar com o seu pai. Quando foi servida uma grande alface com suculentas folhas, ele sugeriu: "Bem, pai, tu comes os filhos e eu fico com a mãe.”

54. Um idiota estava a escrever uma carta de Atenas para o seu pai. Pretendendo mostrar como os estudos lhe estavam a correr bem, acrescentou no pós-escrito: "Faço votos de que na altura em que eu chegue a casa te 
encontres a ser julgado pela tua vida, para que eu possa mostrar-te os meus dotes de advogado."

55. Um idiota jovem e sem recursos vendeu os seus livros quando estava a necessitar de dinheiro. Entáo escreveu ao pai: "Felicita-me, pai, que já estou a realizar dinheiro com os livros!"

56. Um xexé, um careca e um barbeiro foram juntos a uma viagem. Tendo acampado num local remoto, concordaram em ficar alerta aos seus pertences, por turnos de quatro horas. O barbeiro ficou com o primeiro turno. Pretendendo ter um pouco de diversão, rapou a cabeça do xexé enquanto ele dormia. Depois acordou-o assim que o seu turno acabou. Ao esfregar a cabeça quando despertou, o xexé descobriu que estava careca. "Que idiota que esse barbeiro é", resmungou "ele acordou o careca em vez de mim".

57. Quando um idiota teve um filho de uma escrava, o seu pai aconselhou-o a matar a criança. Ele, contudo, objectou: "Primeiro, mata tu os teus próprios filhos, depois já me podes dizer para eu matar o meu."

58. Um funcionário verteu água quente sobre os pés de um totó que foi a umas termas. "Estúpido! Que ideia essa de despejar água quente sobre um homem frio?" 
59. Tendo um idiota ouvido de alguém que tinha tido um bom jantar com uma ave rechonchuda que havia sido morta há algum tempo, dirigiu-se ao seu vendedor de galinhas e solicitou: "Mate-me uma ave que já tenha sido morta há algum tempo!”

60. Um idiota de uma região a muitas milhas de distância tentou torná-la mais próxima. Por tal, retirou sete milhas [do marco de estrada]. ${ }^{16}$

61. O néscio professor da escola primária lançou de repente o olhar sobre o canto e gritou: "Dioniso está a portar-se mal no canto!” Quando um dos outros miúdos salientou que ele ainda não tinha chegado, salientou: "... Assim que chegar."

62. Enquanto assistia aos jogos em honra do milénio da cidade de Roma, um papalvo, ao ver um atleta derrotado lavado em lágrimas: "Não te atormentes", consolou, "tu vais ganhar os próximos jogos do milénio!”

63. Um idiota estava ao serviço de um magistrado cego do olho direito. Um dia passaram por uma vinha. Quando o magistrado estava a elogiar a qualidade das vinhas da esquerda, o idiota acrescentou: "Quando regressarmos hás-de ver que as do outro lado são igualmente boas."

${ }^{16}$ Cf. 131. 
64. Tendo comprado umas calças que eram tão apertadas que mal conseguia vesti-las, um idiota depilou-se.

65. O filho de um imbecil, ao ter sido mandado para a guerra pelo seu pai, prometeu regressar com a cabeça de um inimigo. Então o imbecil proferiu: "Ficarei contente ao ver-te voltar, mesmo sem cabeça!"

66. Ao observar uma barca de trigo de tal maneira cheia, que estava muito afundada na água, um idiota exclamou: "Se o rio subir alguma coisa, [esse barco] ficará afundado.”

67. Um idiota, chegando ao pé do seu sogro, que encontrou de regresso de uma viagem, e ao ser questionado por ele como se encontrava o seu melhor amigo, referiu: "Ele está muito bem e feliz de momento. Com efeito, está a enterrar o seu sogro.”

68. Tendo preparado um pequeno discurso para um cliente, um idiota treinou-o em público. Quando o cliente sugeriu que era uma táctica estranha dar às partes oponentes uma antevisão dos seus argumentoschave, ele retorquiu: "Idiota! Preferias que eu dissesse alguma coisa relevante?"

69. Um tolo foi visitar os pais do seu amigo que tinha acabado de morrer. 
Então, lamentando-se, o pai daquele queixou-se: "Meu filho, deixaste-me devastado!"

E a mãe lamentou-se: "Meu filho, apagaste a luz da minha vida!"

O tolo comentou para os seus amigos: "Se ele na realidade fez tudo isso, merecia ter sido queimado vivo!"

70. Ao chegar para visitar um amigo doente, um idiota foi informado pela esposa que o seu amigo já tinha partido.

- "Então quando ele regressar, diga-lhe que eu estive aqui."

71. Tendo um idiota pensado em comprar algumas roupas e havendo recebido uma amostra para o comprimento e a largura próprios, perguntou então se o tamanho do comprimento e o da largura eram iguais.

72. Tendo estado presente numa recepção de casamento, um tontinho saiu-se com as seguintes palavras: "Que todos os vossos casamentos sejam felizes!"

73. Esse mesmo indivíduo realçou como o sepulcro de Escribónia era belo e opulento, mas acrescentou que tinha sido construído num local insalubre.

74. Alguém comentou com um idiota que tinha um cavalo magro: "O teu cavalo parece estar às portas da morte", ao que ele retorquiu: "E eu também pareço." 
75. Um idiota que estava de cama doente começou a sentir fome. Como a hora da refeição nunca mais chegava, desconfiando do relógio, ordenou que levassem o relógio de sol até si.

76. Um sacerdote, dando a um simplório que chegava ao Templo de Serápis um ramo de árvore, proferiu: "Que o senhor seja misericordioso para ti!"

"Que o senhor seja misericordioso para quem está perto de mim", foi a resposta. "pois eu cá sou um homem livre."

77. Tendo acabado de enterrar o seu filho, um idiota encontrou o professor do rapaz.

"Peço perdão por o meu filho não ter ido à escola", desculpou-se ele, "é que ele morreu". ${ }^{17}$

78. Um idiota estava a exportar umas imagens muito antigas de Corinto. Ao superintender o seu armazenamento nos navios, alertou os marinheiros: "Se vocês perderem estas, vou exigir antiguidades novinhas em folha no seu lugar!”

79. Um copeiro ofereceu uma taça muito quente a um idiota. Este último colocou-a em cima da mesa, pronunciando as seguintes palavras: "Deixe-se ficar aí até que o teu criado chegue e a encontre só quente!”

${ }^{17}$ Cf. 257. 
79 bis. Um imbecil que estava doente prometeu ao médico uma recompensa, caso o curasse. Mais tarde, quando a esposa estava a censurá-lo por beber vinho tendo ainda febre, ele comentou: "Acaso queres que eu melhore e tenha que pagar ao médico a recompensa?"

80. Um idiota encontrava-se num navio que corria o risco de afundar-se numa tempestade. Os outros passageiros começaram a atirar borda fora objectos da sua bagagem, para aliviar o peso do navio, e aconselharam-no a fazer o mesmo. De imediato ele pegou num cheque no valor de cento e cinquenta miríades, apagou o número cinquenta e bradou: "Vejam de quanto eu já aliviei o navio!”

81. Um idiota, a bordo de um navio assolado por uma tempestade, comentou, a propósito dos passageiros que seguiam juntamente consigo e se queixavam: "Porque é que são tâo avarentos? Eu cá paguei dez dracmas a mais e por tal viajo com o risco do capitão."

82. Alguém atirou a um néscio que estava a escalar uma muralha, numa guerra, uma vasilha cheia de esterco. Ele, gritando, disse: "Importas-te de jogar limpo, de futuro?"

83. Quando um barco encalhou no rio Reno, um idiota desceu abaixo da ponte do navio na esperança de elevá-lo, até que alguém lhe disse: "Não percebes que ao teres os teus pés sobre ele estás a afundá-lo ainda mais?” 
84. Esse mesmo indivíduo disse aos seus soldados: "Temos um longo caminho a percorrer amanhá. Por isso, hoje vamos descansar mais!"18

85. Ao ter mudado para uma casa nova, um idiota fez a limpeza à porta da frente e colocou um aviso a dizer: "Quem quer que despeje excrementos aqui, têlos-á que dar como perdidos."

86. Um imbecil a quem o seu pai se preparava para bater por ter perdido um denário, suplicou: "Não estejas irritado, que eu comprar-te-ei outro denário com o meu dinheiro."

87. Um idiota encontrou uma armadura de gladiador dentro de casa e começou a divertir-se com ela. De repente, alguém o alertou que o seu pai tinha regressado. Ele pousou o escudo e começou a tirar a armadura. Todavia, o seu pai entrou antes que ele pudesse ter acabado. Então ele pegou num livro e fingiu estar a ler - mas com o capacete ainda na cabeça.

88. Quando escalou uma montanha escarpada ao regressar a casa de uma viagem, um simplório, admirado, constatou: "Não consigo entender. Da primeira vez que passei por aqui era uma descida. Como é possível que tenha mudado tão depressa para uma subida?"

${ }^{18}$ Cf. 134. 
89. Durante uma viagem marítima, um idiota perguntou ao timoneiro que horas eram. Quando nele disse que não sabia, inquiriu há quanto tempo é que ele era um timoneiro.

- "Há três anos."

- "Então como é que é possível que eu, que comprei uma casa há apenas seis meses, consiga dizer a hora baseado apenas no momento em que o sol brilha na parede, mas tu não consigas dizer, a partir da posição do barco, depois de todo esse tempo como timoneiro?”

90. Um professor idiota, cujos discursos em honra dos mortos eram sobejamente conhecidos, compôs o epitáfio de um indivíduo ainda em vida. Quando interpelou o idiota a esse respeito, ele replicou: "Acaso não prefere dar uma leitura prévia, não vá eu, depois, quando morrer, fazer afirmaçóes erradas, de improviso?"

90 bis. Um idiota prestes a naufragar pediu uma tabuinha para escrever o testamento.

91. Um imbecil convidou alguns amigos para jantar. Eles elogiaram a cabeça do porco e pediramlhe para degustar outra ao jantar, no dia seguinte. De imediato, ele foi ao talho e pediu: "Dê-me uma outra cabeça para o mesmo porco. Aquela de ontem deu-nos muita satisfação.” 
91 bis. Pretendendo atravessar um rio, um idiota apanhou um barco montado no seu cavalo. Quando the perguntaram por que razão não tinha desmontado, ele alegou estar com pressa!"

92. Um idiota perguntou ao seu pai: "Quanto é que um frasco de cinco litros leva?"19

93. Tendo verificado que uma escada tinha vinte degraus a subir, um néscio procurou indagar quantos é que tinha a descer.

94. No decurso de uma conversa sobre indigestão, um idiota referiu nunca ter sofrido disso.

- "Mas tu nunca tens um arroto azedo e a saber mal?”, perguntaram os outros.

- “Sim, todos os dias."

95. Um idiota que tinha acabado de ter um filho rapaz foi questionado por alguns amigos que nome iria dar-lhe.

- "Ele terá o meu nome e eu cá me arranjarei sem um.”

96. Era uma vez dois idiotas cobardes. Um escondeu-se num poço e o outro num canavial. Quando os soldados que estavam atrás deles mergulharam um capacete para beber água, o que estava no poço

${ }^{19}$ Cf. 136, 265. 
pensou que um soldado tinha descido para ir buscá-lo. Começou a pedir clemência e foi detectado. Como os soldados dissessem que o deixariam ir em liberdade se ele se calasse, ao ouvir isto, o outro idiota escondido no canavial vociferou: "Deixem-me também em liberdade; eu também estou calado!”

96 bis. Tendo aceitado um convite para jantar, um imbecil não estava a comer nada.

Quando alguém lhe perguntou por que motivo não comia, ele replicou:

"Porque não quero que as pessoas pensem que vim só para comer!”

97. Um idiota foi comprar um caixão para a sua mulher, que tinha acabado de morrer, mas entrou em discussão com o cangalheiro sobre o preço. Este jurava que não poderia vender por menos cinco miríades.

- "Está bem. Aqui estão cinco miríades, já que estás obrigado pelo teu juramento. Mas dá-me também um pequeno sarcófago, pronto para usar para o meu filho, caso ele precise de um."

98. Um idiota, ao encontrar um outro, disse: "Felicito-te pelo nascimento do teu filho." O outro comentou: "Sim, graças a uma ajudinha dos amigos!"

99. Alguém pediu a um tolo: "Empresta-me um manto até ali ao campo."

- "Bem, eu tenho um que dá até aos tornozelos 
- disse -, mas receio náo ter nenhum que dê até ao campo." 20

100. Um idiota estava a viajar numa carruagem. Quando as mulas se cansaram e não puderam prosseguir, o cocheiro libertou-as das correias para descansarem um pouco. Contudo, assim que ficaram livres, fugiram.

Então o idiota verbalizou para o cocheiro: "Tolo! Então não vias que não eram as mulas que não conseguiam correr, mas era a carroça." ${ }^{21}$

101. Um néscio, vendo dois irmãos gémeos $\mathrm{e}$ admirando-se com a semelhança deles: "Este - comentou não se parece tanto ao outro como o outro se parece a este."

102. Diz alguém a um idiota: "Démeas, vi-te em sonhos [aqui mesmo] há três dias atrás."

- "És um mentiroso - retorquiu ele - não podes ter visto. Eu estava no campo.”

103. Um idiota estava a discutir com outros dois. Um afirmava que era errado matar ovelhas, já que forneciam leite e lá. Outro defendia que era errado matar vacas, uma vez que elas forneciam leite e puxavam $\mathrm{o}$ arado. O idiota disse que não era justo matar porcos, porque eles forneciam fígado, úbere e um útero. ${ }^{22}$

\footnotetext{
${ }^{20}$ Cf. 137.

${ }^{21}$ Cf. 128.

${ }^{22}$ Cf. 129.
} 


\section{Sobre Avarentos}

104. Um avarento colocou-se a si mesmo como herdeiro no próprio testamento.

105. Um sovina, questionado sobre o motivo pelo qual só comia azeitonas, afirmou: "Porque posso usar a casca como adubo; o caroço como lenha; e besunto-me todo da cabeça aos pés com ela, ao comer, pelo que não preciso de banho."

106. Um homem já maduro tinha o hábito de fingir para a sua namorada que era de família nobre e era rico. Quando a namorada o encontrou de repente a alimentar-se em casa dos seus vizinhos, ele virou-se e disse: "Faça o favor de enviar-me o meu fato de jantar, está bem?”

107. Havia um outro semelhante, sempre a gabar-se, quando na realidade não tinha um chavo. Um dia a sua namorada foi dar com ele caído entre arbustos. Voltando-se, culpou os médicos, comentando: "Os melhores e mais reputados médicos da cidade recomendaram-me dormir nos arbustos.”

108. Um charlatão, avistando no mercado o seu escravo acabado de chegar do campo, disse "Como estão as ovelhas?" Ele, por seu turno, respondeu: "Uma está a dormir; a outra está acordada." 
109. Um simplório que estava envolvido num processo de tribunal, tendo ouvido que os julgamentos mais justos eram os do Hades, enforcou-se.

\section{DE ABDERA}

110. Abdera era uma cidade dividida em dois distritos, com metade da população a viver a Este e a outra metade a Oeste. Um dia, os inimigos atacaram a cidade, criando o pânico geral. Mas as pessoas que habitavam no lado Este em breve se recompuseram e disseram:"Não há motivo para ficarmos em pânico. Os guerreiros estão a dirigir-se para as muralhas do Oeste.”

111. Certa vez um jumento escapou em Abdera, entrou num ginásio e derrubou o recipiente de azeite. Para se certificarem de que isto não voltaria a suceder, os habitantes reuniram-se, cercaram todos os burros na cidade, juntaram-nos num lugar e espancaram o burro culpado à sua frente.

112. Um habitante de Abdera estava a tentar enforcar-se, quando a corda partiu e feriu a cabeça. Por isso foi a um médico para um curativo, aplicou-o no ferimento, foi-se embora e depois enforcou-se.

113. Ao ver um [eunuco] com um edema a sair de umas termas, um habitante de Abdera gritou: 
"Parece-me que tu deves ser o criado das termas. Deixa aqui a água!"

114. Ao ver um eunuco, um habitante de Abdera perguntou-lhe quantos filhos tinha. Ele respondeu que não tinha nenhum, já que não possuía testículos, nem tinha meios de reprodução. Em resposta, <...>

115. Ao ver um eunuco a conversar com uma mulher, um habitante de Abdera demandou-lhe se era a sua esposa. Mas tendo o eunuco respondido que não podia ter mulher, aquele referiu "Entáo deve ser a tua filha."

116. Havia um eunuco de Abdera que tinha ainda a desventura do edema. ${ }^{23}$

117. Um habitante de Abdera estava a dormir na companhia de um indivíduo com um edema. À noite teve de levantar-se e, quando estava a voltar para a cama, acidentalmente pisou o edema, devido à escuridão. $\mathrm{O}$ indivíduo que tinha o edema gritou de agonia, ao que ele lhe disse: "Porque é que estavas a dormir virado para baixo?”

118. Um [transeunte] de Abdera avistou um doente com edema a urinar e comentou: "Este, mesmo urinando de manhã até à noite, não conseguirá urinar tudo."

${ }^{23}$ Cf. 252. 
119. Ao ver uma vítima de edema a sair de uma piscina, mostrando dificuldade, um habitante de Abdera disse-lhe: "Porque é que te empanturraste com tanta água? Obviamente não consegues levantar-te com decência!”

120. Um habitante de Abdera tinha ouvido que cebolas e bolbos causavam ventos. Por isso, quando estava a velejar num dia sem vento, encheu um saco deles e dependurou-o na popa do navio. ${ }^{24}$

121. Ao ver um corredor que tinha sido torturado, um habitante de Abdera salientou: "Pelos deuses, agora ele já não corre, mas voa!”

122. Um natural de Abdera estava a tentar vender um vaso sem pegas. Tendo-lhe sido indagada a razão por que retirara as suas orelhas: "Para que, ao ouvir que ia ser vendido, não fugisse.”

123. Um habitante de Abdera cremou o seu falecido pai de maneira usual. Depois correu para casa e disse à sua mãe, que também estava doente: "Ainda sobraram algumas brasas quentes. Se quiseres agora e se não te custar, [levanta-te] e vai cremar-te."

124. Um cidadão de Abdera sonhou que estava a vender um porquinho e pedia a quantia de cem

${ }^{24}$ Cf. 141. 
denários. Acordou no momento em que estava a recusar uma oferta de cinquenta denários. Voltou a fechar os olhos, esticou a mão e suspirou: "Está bem, dê-me então os cinquenta."

125. O pardal de um habitante de Abdera morreu. Algum tempo depois, ao contemplar um pardal, lamentou: "Se a minha ave estivesse viva, seria agora tão grande como essa.”

126. Um residente de Abdera de visita a Rodes cheirou as muralhas para comprovar se a cidade era tão rosada como o nome sugeria.

127. Ao estar a dever um burro, que não tinha, um habitante de Abdera perguntou se podia pagar na forma de duas mulas.

\section{SidónIOS}

128. Um governador sidónio estava a viajar numa carruagem. Quando as mulas se cansaram e não puderam prosseguir, o cocheiro libertou-as das correias para descansarem um pouco. Contudo, assim que ficaram livres, fugiram.

Então o governador disse para o cocheiro: "Vês, tolo, que não eram as mulas que náo conseguiam correr, era a carroça?"

129. Um orador sidónio estava a discutir com 
outros dois. Um afirmava que era errado matar ovelhas, já que forneciam leite e lá. Outro defendia que era errado matar vacas, já que elas forneciam leite e puxavam o arado. O retórico disse que náo era justo matar porcos, porque eles forneciam fígado, úbere e rins.

130. Ao entrar nos banhos públicos (termas) à hora de abertura e não encontrando lá viv'alma a banharse, um sábio sidónio disse para os criados particulares: "Pelo que vejo, não está a lavar."

131. Um sidónio idiota de uma região a muitas milhas de distância, tentou torná-la mais próxima e retirou sete milhas [do marco de estrada].

132. Um negociante sidónio viajava com outro. Um deles, forçado pelo intestino, viu-se obrigado a retirar-se um pouco. $\mathrm{O}$ companheiro de viagem chegou até ele escrevendo no marco da estrada: "Despacha-te! Apanha-me!” E ele, quando leu, escreveu por baixo: "E tu espera por mim!"

133. Diz alguém a um pescador sidónio: "A tua bos $(l)$ sa tem caranguejos?" Ele, furioso, inquiriu: "O teu inchaço tem caranguejos?"

134. Um capitão sidónio disse seus soldados: "Descansem hoje muito, pois amanhã temos que viajar bastante!" 
135. Alguém diz a um comerciante de velas sidónio: "Ò mestre, tem alguma frieira a queimar quero dizer, alguma coisa que queime o frio?" E ele, irritado, perguntou: "E o senhor tem úlceras - isto é, carvão?”

136. Um aluno perguntou a gramático sidónio: "Quanto é que um frasco de cinco litros leva?" E ele respondeu: "Referes-te a vinho ou a azeite?"

137. Alguém pediu a um cozinheiro sidónio: "Empresta-me uma faca até Esmirna." Mas ele retorquiu: "Não possuo uma faca que dê até lá."

138. Um centuriáo sidónio avistou um carroceiro a conduzir a sua carroça pela ágora e ordenou que recebesse castigos físicos. Contudo, ele alegou que era um cidadão romano e que era contra a lei feri-lo. Então, o centuriáo ordenou que o boi fosse açoitado.

139. Um médico sidónio recebeu uma herança de mil dracmas no testamento de alguém que tinha sido seu paciente. Apareceu no funeral e queixou-se da mesquinhez da sua parcela. Depois, quando o filho do falecido ficou doente, chamou-o. O doutor disse ao doente: "Deixa-me cinco mil dracmas no teu testamento e eu irei tratar-te da mesma maneira que tratei o teu pai." 


\section{ENGRAÇADINHOS}

140. Um engraçadinho, ao ver um professor primário a recapitular as suas liçôes de língua, perguntou-lhe por que razão não ensinava lira. Este respondeu: "Porque não sou um músico." E ele disse: "Então porque é que tenta ensinar língua, quando é iletrado?”

141. Quando lhe perguntaram de que lado estava a soprar o vento, um timoneiro engraçadinho respondeu: "Do lado dos feijōes e das cebolas."

142. Um médico [mãos leves] roubou uma lâmpada de um engraçadinho com conjuntivite, que estava a tratar. Depois perguntou-lhe: "Como é que os olhos estão?" E o engraçadinho responde: "É curioso, desde que me tratou, não consegui mais ver a minha lâmpada."

143. Alguém se queixou a um médico divertido: "Estou coberto de inflamaçóes." Ao que aquele afirmou: "Bem, se vive abrasado, não espere estar fresco."

144. Um engraçadinho comentou, ao ver um corredor lento: "Eu sei do que é que aquele indivíduo precisa."

- "De quê?", indagou o árbitro.

Ele retorquiu: "De um cavalo, caso contrário, não consegue apanhar os outros corredores!" 
145. Ao apanhar a esposa na cama com um sargento, um comerciante bem-humorado disse: "Encontrei aquilo por que não procurava!"

146. Um engraçadinho roubou um porco e fugiu. Quando foi apanhado, pôs o porco no chão, açoitou-o e disse: "Faz as tuas escavadelas aqui, não na minha propriedade!"

147. Ao deparar-se com um músico mal sonante e desafinado, um engraçadinho saudou-o, mencionando: "Viva, ó galo!" Quando ele lhe perguntou porque o tratara assim, explicou: "Porque quando tu começas a cantar, toda a gente se levanta".

148. Um barbeiro tagarela perguntou a um engraçadinho: "Como é que eu devo cortar o teu cabelo?". "Em silêncio" - disse ele.

149. Uma disputa iniciou-se numas termas, entre um engraçadinho e um outro indivíduo. Quando o caso chegou a tribunal, o engraçadinho arrolou os empregados das termas como testemunhas. $\mathrm{O}$ advogado de defesa afirmou que esses indivíduos não eram merecedores de confiança. "Bem, objectou o engraçadinho, se eu tivesse sido insultado no interior do Cavalo de Tróia, teria chamado os delegados de Menelau, Ulisses e Diomedes como testemunhas. Uma vez que o incidente ocorreu numas termas, parece razoável que os funcionários das termas estejam mais bem posicionados para contar o 
que aconteceu."

150. Enquanto estava numas termas, dois indivíduos pediram duas vezes a um engraçadinho para emprestar uma esponja. Um dos que pediu era desconhecido. $\mathrm{O}$ outro ele reconheceu-o como um ladrão. Então disse: "A ti, não te conheço, não empresto. A ti, conheço-te e não empresto.”

151. Vendo um chulo a anunciar uma prostituta negra, um engraçadinho perguntou: "Quanto é que cobra pela noite?"

151 bis. Quando viu um médico a ungir uma rapariga, um homem bem-humorado aconselhou: "Vê lá, jovem, se ao tratar da aparência não desgastas a rapariga." ${ }^{25}$

152. Dois parricidas engraçadinhos estavam a queixar-se um ao outro que os seus pais, os quais eles detestavam, ainda estavam vivos. Então um deles disse para o outro: "Para que náo sejamos apontados como parricidas por ninguém, tu matas o meu pai; eu o teu, e escapamos da má reputação.”

153. Um lutador bem-humorado caiu na lama. Não querendo parecer um principiante, rebolou até estar completamente coberto de lama e depois ergueuse com toda a pose.

${ }^{25}$ Cf. 260. 


\section{Cidadáos de Cumas}

154. Em Cumas, alguém perguntou aos condolentes do funeral de um distinto cidadão: "Quem é o morto?" Um dos habitantes de Cumas voltou-se e apontou o dedo, esclarecendo: "É aquele ali, que vai estendido no carro fúnebre".

155. Alguém perguntou a um habitante de Cumas, que estava a vender um cavalo, se ele já tinha posto abaixo a primeira dentição. Afirmando que já era a segunda dentição, acrescentou: "Como sabes? perguntou ele - Porque ele já me deitou abaixo uma vez a mim e outra ao meu pai."

156. Estando a vender uma casa, um cidadão de Cumas andava carregado com uma pedra retirada dela para mostrar às pessoas como é que era.

157. Um cidadão de Cumas estava a vender um cavalo, quando lhe perguntaram se ele tinha receio de alguma coisa. "Pela saudinha do meu pai, penso que não!", respondeu ele. "Na realidade ele fica sozinho na estrebaria!"

158. Um cidadão de Cumas comprou umas roupas roubadas e, para evitar que fossem descobertas, assinalou-as.

158 bis. Um cidadão de Cumas tinha um cavalo 
para venda. A um possível cliente que veio até si e o inquiriu acerca da sua dentição, ele indagou: "Porque é que estás tão interessado a respeito dos seus dentes? Tomara eu que ele se movesse da mesma maneira como come!"

159. Um homem de Cumas construiu um grande logradouro, colocou a esposa no extremo oposto a si e perguntou-lhe se conseguia vê-lo.

- "Por pouco", disse ela.

- "Então quando tiver oportunidade farei um tão grande que náo serei capaz de ver-te a ti, nem tu a mim."

160. Um homem de Cumas que procurava um amigo pôs-se à frente da casa dele a gritar pelo seu nome. - "Grita mais alto para ele te ouvir", aconselhou um transeunte.

Então ele começou a gritar: "Mais alto!”

161. Um homem de Cumas arrombou a casa de um usurário. Pretendendo roubar as dívidas maiores, saiu com os ficheiros mais volumosos.

162. Quando os habitantes de Cumas estavam a fortificar a sua cidade, um deles, chamado Loliano, completou duas das secçóes mediais a expensas próprias.

Irritados com isso, os concidadãos concordaram que, face a um futuro ataque inimigo, ninguém iria ajudar Loliano a defender a sua secção do muro. 
163. Os habitantes de Cumas ansiavam pela chegada de um distinto aliado. Pretendia honrá-lo com um banho de água fresca. Mas tinham apenas umas termas. Então o que fizeram foi encher a piscina com água quente. Depois colocaram uma grelha a meio, a fim de manter fresca metade da água, para quando o aliado chegasse.

164. Um homem de Cumas tinha ido nadar, quando começou a chover. Entáo ele mergulhou para o fundo, para evitar molhar-se.

165. Ao comprar umas janelas, um homem de Cumas perguntou se elas podiam voltar-se para Sul.

166. Um homem de Cumas estava a percorrer um jardim, montado num burro. Ao topar com um ramo carregado de figos, tentou agarrá-lo, mas o burro fugiu e deixou-o pendurado. $\mathrm{O}$ jardineiro chegou e exigiu saber o que é que ele fazia ali pendurado, ao que ele retorquiu: "Caí do burro!"

167. Ao ver uma ovelha com as patas atadas a ser tosquiada, um homem de Cumas referiu: "Ainda bem que o meu barbeiro não me amarra antes de me cortar o cabelo!”

168. Enquanto o pai se tinha ausentado numa viagem, um habitante de Cumas cometeu um crime grave e foi condenado à morte. Quando estava a ser 
levado, pediu a ajuda de todos para que o seu pai não soubesse, pois certamente iria dar-lhe uma surra de morte quando voltasse.

169. Esse mesmo indivíduo, a uma pessoa que havia gritado "Estás a roubar-me!":

- "Que eu nunca volte do sítio para onde estou a fugir, <referiu>, se eu alguma vez te roubei!"

170. Um estranho perguntou a um cidadão de Cumas se ele sabia onde vivia o retórico Dracôntides. "Desculpe, estou sozinho - disse - mas se ficar aqui e tomar conta da minha loja, terei todo o gosto de sair e de lhe indicar a casa dele.

171. Um homem de Cumas entregou o corpo do seu pai que tinha falecido em Alexandria a um embalsamador. Voltou mais tarde para ir buscá-lo, mas o embalsamador, que estava rodeado de outros corpos, perguntou que marca distintiva é que o seu pai tinha.

- “Tossia muito."

172. Ao ver um lutador de boxe coberto de feridas, um homem de Cumas perguntou como é que ele as tinha obtido. Em jeito de resposta: "Foi uma espécie de formigueiro", respondeu.

"Então e porque é que dormiste no chão?"

173. Um homem de Cumas estava a vender mel. 
Como um cliente o tivesse provado e salientado o quão bom era, ele comentou: "Se aquele rato não tivesse aí caído, eu nunca o venderia!

174. Um médico desenganara um paciente de Cumas. Todavia, tendo melhorado, começou a evitar encontrar-se com o médico. Por fim, este último conseguiu encurralá-lo e perguntar-lhe o porquê.

- "Bem, eu sinto-me embaraçado de ser visto vivo depois de o doutor ter dito que eu ia morrer."

175. Um doutor de Cumas tinha um paciente com febre terciária. Ele conseguiu debelá-la pela metade e contentou-se com metade do preço da consulta.

175 bis. Um indivíduo, ao consultar um médico idiota de Cumas, disse:

- "Doutor, sempre que me levanto depois de dormir, sinto-me zonzo durante uma meia hora, <mas depois fico bem."

Ao que o médico respondeu:

- "Então espere meia hora antes de despertar.">

176. Um doutor de Cumas tinha um paciente que havia desenganado, mas mesmo assim deu-lhe um clister e recomendou ao assistente que examinasse o que sairia dali. Mas quando o informou que o paciente tinha morrido, o doutor afirmou: "De qualquer forma ele teria estalado, com clister ou sem clister." 
177. Um doutor de Cumas, ao operar um paciente que estava a sofrer terrivelmente e a gritar desalmadamente, mudou para um bisturi menos duro.

178. Dois habitantes de Cumas seguravam com todas as forças dois cestos de figos. Cada um deles começou sub-repticiamente a comer do cesto do outro e não do seu próprio. Quando acabaram de consumir o conteúdo do cesto do outro, cada qual voltou-se para o seu próprio cesto e encontrou-o vazio. Entáo dirigiramse ao magistrado da cidade e apresentaram queixa um do outro. Ao tomar conhecimento, o magistrado ordenou que trocassem os cestos vazios e que cada um restituísse ao outro o seu valor.

179. Em Cumas, um demagogo acusado proferiu a seguinte alegação diante de uma assembleia:

- "Senhores cidadáos - disse -, se considerarem que sou vítima de acusaçóes difamantes por parte dos meus rivais, peço-vos que os reprimam. Mas se eu for culpado de alguma das acusaçóes, permaneçam sentados e vejam o tecto desabar apenas sobre mim!

180. O arconte de Cumas proferiu estas proclamaçóes: "Os éforos deverão levar de imediato ao sacerdote, depois do sacrifício, as peles de todas as vítimas. Os membros da assembleia deverão ir ao conselho, mas sem deliberar. Os talhantes deverão depor sobre a muralha os próprios ossos. Os que forem 
sapateiros não deverão deixar desaparecer as pequenas formas de calçado.”

181. Tendo todos os cidadáos de Cumas sido convocados para uma eleição, ficaram a saber que muitos indivíduos das regióes mais afastadas não tinham vindo apresentar os seus votos devido à distância.

- "Não é culpa nossa, argumentaram, se não formos capazes de viajar no futuro."

182. Ao estar a fazer uma operação numa ferida da cabeça, um <doutor $>$ de Cumas virou o paciente de costas e enfiou-lhe água na boca para ver $<$ se $>$ iria fluir pelo buraco feito na cabeça.

\section{Mal-humorados}

183. Um indivíduo chegou-se ao pé de um médico mal-encarado e disse: "Doutor, não consigo deitar-me, ficar em pé, nem sentar-me.” $O$ médico retorquiu: "Então o único remédio é enforcar-se."

184. Um paciente disse a um médico malhumorado: "O que hei-de fazer, uma vez que estou a perder sangue pelas minhas fezes e na bílis do meu fígado?", ao que aquele lhe disse: "Se revirar as suas tripas, eu não ficarei com maus fígados!”

185. Um médico mal-humorado que só tinha um 
olho perguntou a um paciente: "Como está?", ao que ele respondeu: "Estou como pode ver." Então o médico disse: "Se está como eu posso ver, então metade de si está morta!"

186. Um doutor visitou um paciente malencarado, examinou-o e comentou: "Está a transpirar duro e feio!" Por seu turno, ele redarguiu: "Se conseguir transpirar melhor, aqui está a cama. Deite-se e transpire!"

187. Um astrólogo misantropo fez o horóscopo de um rapazinho enfermo, dizendo à mãe que ele iria viver por muito tempo. Quando depois exigiu o pagamento, ela disse: "Volte amanhã e eu dou-lho então", ao que ele questionou: "Mas e se ele morrer de noite? Eu perderei o pagamento?"

188. Perguntou-se a um homem mal-humorado, que tinha comprado um frasco de mel, quanto tinha pagado por ele. Voltando o jarro de cabeça para baixo, respondeu: "Que o meu sangue flua assim, se eu vos disser!”

189. Um médico, indo ao encontro de um paciente mal-encarado, recomendou que ingerisse pedacinhos de saponária. E o mal-humorado disse: "Como serei capaz de ir até à cómoda para ingerir apenas uns pedacitos de saponária?

190. Enquanto jogava um jogo de tabuleiro, um 
homem mal-humorado estava furioso com uma pessoa que se encontrava sentada languidamente a atrapalhá-lo.

Irritado, ele inquiriu-o: "Qual é a tua profissão, e já agora, porque é que não estás a trabalhar?” E o outro disse-lhe em resposta: "Sou um alfaiate, mas não tenho emprego."

Ele fez um buraco na sua capa, entregou-lho e ordenou: "Toma! Trabalha e cala-te!"

191. Alguém perguntou a um indivíduo de maus fígados: "Onde é que vive?" Ele respondeu: "Estou a mudar-me de lá."

192. Um indivíduo chegou-se junto a um capitão mal-humorado e disse: "Eu vi-te em Rodes quando fundeaste lá o teu navio." Em resposta o outro disse: "E eu vi o fundo do teu fígado na Sicília!"

193. Alguém foi à procura de um homem malencarado. Então ele gritou: "Não estou em casa!"

Consequentemente, o outro riu-se e refutou: "Mentes! Então eu ouvi a tua voz!" Ele exclamou:

"Francamente! Se o meu escravo tivesse dito que eu não estava, tu terias acreditado! Quer dizer que preferias acreditar num escravo do que em mim?”

194. Enquanto descia as escadas da sua habitação, um homem mal-humorado tropeçou e caiu.

Questionado pelo senhorio "O que é que se passa aí?", respondeu: "Eu gritei por um motivo doméstico. 
O que é que tens a ver com isso?”

195. Disse um indivíduo a um senador malencarado: "Espero ver-te em pouco!" Ele replicou em resposta: "E eu cá desejo ver-te cego e coxo!"

\section{EsTúpIDOS}

196. Um professor estúpido, fora questionado como devia dizer-se: dois' ou 'ambos'? Ele ergueu a mão e fez um gesto com dois dedos.

197. Um professor estulto foi questionado: "Como se chamava a mãe de Príamo?" Sem outra escapatória, afirmou: "Nós chamamo-la, pelo seu valor, de 'Senhora'”.

198. Um barbeiro incompetente estava a fazer curativos aos clientes que tinha cortado. Mas tendo um deles reclamado, ele disse: "Não tem porque se queixar! Apenas cobro um denário pelo corte, mas fica ainda com curativos que me custam quatro denários!

199. Um aprendiz bagunceiro que fez uma trapalhada ao cortar o cabelo de um cliente e foi esbofeteado quando fez um trabalho igualmente mau de manicura, clamou: "Patrão, porque é que ele não me dá uma oportunidade para aprender?

200. Um aprendiz estúpido começou a chorar 
quando o seu patrão lhe mandou arranjar as unhas de um cliente. Quando este lhe perguntou porquê, ele retorquiu: "Estou a chorar porque tenho medo! Eu sei que vou aleijá-lo, sei que irá aleijar-me e eu sei que o meu patrão me irá bater até mais não.

201. Como um indivíduo que tinha estado ausente da pátria fosse ao encontro de um profeta estúpido, indagou a respeito da família. E ele declarou: "Estão todos bem de saúde e o teu pai também." Mas tendo ele argumentado que "Então o meu pai não morreu já há dez anos", o indivíduo respondeu-lhe: "Pois não sabes nada acerca do teu pai verdadeiro."

202. Ao fazer o horóscopo de um rapaz, um profeta néscio previu: "Primeiro vais ser um retórico, depois um prefeito e finalmente um magistrado de província." Todavia o rapaz morreu. A mãe voltou e protestou: "Aquele que o senhor disse que iria ser um retórico, um magistrado e um governador, faleceu." E ele disse: "Eu juro pela sua memória que ele teria sido tudo isso se tivesse vivido!"

203. Alguém foi a um profeta estúpido e indagou se o seu rival regressaria de viagem. O profeta garantiu que ele não iria conseguir. Mas quando descobriu uns dias mais tarde que ele tinha voltado, afirmou: "Bem, nada poderia ser mais descarado do que ele."

204. Um profeta tacanho fez o horóscopo a 
um cliente e declarou: "Não poderá vir a ter filhos." Porém aquele retorquiu: "Mas eu já tenho sete!" E ele argumentou: "Então é bom tome bem conta deles."

205. Um profeta estúpido foi capturado pelo inimigo e confessou a natureza do seu negócio. Sucedia então que eles estavam para travar uma batalha. "Vocês vencerão - asseverou-lhes -, contando que o inimigo não veja os cabelos na parte de trás das vossas cabeças, no meio da luta”.

\section{Cobardes}

206. Perguntou-se a um cobarde: "Que navios são mais seguros - navios de guerra ou navios mercantis?

"Navios atracados." - foi a sua resposta.

207. Tendo passado a noite inteira a sonhar que estava a ser perseguido por um urso, um caçador cobarde comprou uns cães e pô-los a dormir consigo.

208. Alguém perguntou a um boxeador medroso: "Com quem é que vai lutar?"

Indicando o seu oponente, ele bajulou: "Com este meu senhor e mestre aqui!"

209. Ao tomar muitos golpes do seu oponente, um boxeador cobarde gritou: "Preciso que não batam 
[todos] ao mesmo tempo!"26

210. Ao comprar uma terra, um boxeador cobarde pediu aos locais que lhe garantissem que não tinha picadas.

\section{Preguiçosos}

211. Enquanto dois preguiçosos estavam juntos na cama, um ladrão apareceu e tentou levar o cobertor. Um deles viu o que estava a passar-se e disse ao outro: "Detém-no, ele está a roubar o cobertor", e o outro tranquilizou: "Náo te preocupes. Vamos esperar que ele regresse para o colchão; então apanhamo-lo.”

212. O pai de um rapaz ocioso mandou-o ir a casa do seu vizinho e pedir um machado emprestado. $\mathrm{O}$ jovem respondeu: "Eu sou o teu vizinho, não sou? Não tenho nenhum machado."

213. Um sorna devia a outro sorna um denário. Quando se encontraram, o credor pediu o denário de volta. Disse então: "Está bem, estica a tua mão, desata o meu lenço de bolso e retira daí o denário." O outro disse: "Deixa lá! Não me deves nada!"

${ }^{26}$ Cf. 218. 


\section{INVEJOSOS}

214. Um homem invejoso foi a um pisoeiro, não conseguiu urinar e morreu.

215. Quando viu os seus inquilinos a passar um bom bocado, um homem invejoso despejou-os de casa.

216. Ao ver o seu vizinho a lutar com animais selvagens, um homem invejoso disse ao juiz oficial: "<Traga> o urso!"

\section{$<$ COBARDES $>$}

217. Um indivíduo, por causa da cobardia, escreveu na sua fronte: "Este sitio contém órgãos vitais." Mais tarde, quando estava a levar socos ininterruptamente, virou-se para os espectadores e gritou: "Este tipo não consegue ler e está a desfazer-me!”

218. Debaixo de uma chuva de pancadaria por parte do seu opositor, um boxeador cobarde gritou: Misericórdia, não me batam todos ao mesmo tempo!

\section{GLUTÓES}

219. Um glutão prometeu a filha em casamento a outro glutáo. Quando questionado o que tencionava trazer para dar-lhe como dote: "Dou uma casa - replicou ele - com janelas viradas para a padaria." 
220. Um professor glutão, ao avistar um pão que estava dependurado, proferiu: "Desces?... Dás a resposta, ou subo e vou acabar contigo?”

221. Ao ver um pão com um buraco, um médico glutão recheou-o com um curativo.

222. Como parte do seu tratamento, um médico disse a um paciente comilão para juntar alguma moagem às suas bebidas. Se não encontrasse moagem, que lhes pusesse, do mesmo modo, farinha de aveia. Todavia, o comilấo questionou: "E se eu não conseguir apanhar $a$ veia, como duas artérias no seu lugar?"

223. Ao avistar um naco de pão numa prateleira alta, um glutấo suplicou: "Deus, torna-me mais alto ou a prateleira mais baixa!"

224. Um lambão, tendo-se aproximado de um jardineiro, ofereceu-lhe quatro denários pelo direito de comer todos os figos que quisesse.

Pensando nisso, este disse: "Pode ficar com todos os figos que conseguir comer destas árvores."

[O lambão] trepou às árvores mais altas e começou, a partir do cimo, a comer todos os figos na descida.

Muito mais tarde, o jardineiro lembrou-se dele e foi à sua procura. Quando o viu no alto das árvores a abanar os ramos e a comer deles, gritou de raiva: "Náo 
podias ter permanecido cá em baixo e comido dos ramos mais baixos?" Então ele respondeu: "Assim que descer, como esses!"

225. Um glutão chegou-se ao pé de um padeiro e ofereceu-lhe dois denários em troca do direito de comer todo o páo que lhe apetecesse.

O padeiro aceitou os denários e concordou, julgando que um pão deveria ser o suficiente.

Todavia, decidido a comer, o [glutão] começou pelo cesto de páo, pôs-se ao pé dele e devorou metade do seu conteúdo.

Admirado e aborrecido, o padeiro sugeriu: "Porque é que não se senta e come?"

- "Prefiro ficar em pé até ter acabado os pães do cesto. Depois sentar-me-ei para o resto.”

226. Um actor cómico alarve pediu ao seu encenador que lhe providenciasse uma refeição antes de ir para o palco. E ao averiguar a razão por que desejava uma refeição prévia, "Para não cometer perjúrio disse - ao clamar 'Juro por Ártemis que nunca comi mais agradavelmente!'”

\section{Alcoólicos}

227. Alguém chegou junto de um alcoólico que estava a beber num bar e informou: "A sua esposa morreu." Tendo ouvido, ele disse para o taberneiro: "Serve, por conseguinte, vinho tinto!" 
228. Um bêbedo estava a ser criticado por alguém, por beber tanto, que o seu juízo estava estropiado.

Não conseguindo ver bem devido ao vinho, expressou: "Estou a ver coisas, ou tu tens duas cabeças?”

229. Um alcoólatra fracassado herdou uma vinha, mas teve o azar de morrer na altura das vindimas.

230. Um alcoólico abriu uma taberna e amarrou um urso à entrada.

\section{Os QUE TÊM MAU HÁLITO}

231. Um homem com mau hálito decidiu matar-se. Então cobriu a cara e morreu asfixiado.

232. Um homem com mau hálito começou a beijar a sua esposa apaixonadamente, dizendo: "Minha senhora, minha Hera, minha Afrodite!"

Voltando a cabeça, ela sussurrou: "Ó meu Zeus, ó meu Zeus!”

233. Um homem com mau bafo encontrou uma pessoa surda e disse: "Bom dia!" O outro retorquiu: "Pf!" Então ele inquiriu: "O que é que eu fiz?" Aquele respondeu: "Peidaste-te!"

234. Um homem com mau hálito perguntou à 
sua mulher: "Minha querida, porque é que me odeias?" Ela respondeu, dizendo: "Porque tu me amas."

235. Um homem com halitose foi a um médico e referiu: "Olhe, doutor, a minha úvula está baixa." E, como tivesse aberto a boca, o médico, desviando-se, constatou: "Não foi a sua úvula que desceu, mas a sua bunda que subiu!"

236. Um homem com mau hálito estava a mimar o seu filho, oferecendo-lhe pequenos bocados de comida da sua boca. Porém, afastando-se, ele afirmou: "Não quero, papá, é caca!"

237. Um homem com mau hálito estava a cozinhar um enchido, mas debruçou-se tanto sobre ele que se transformou num excremento.

237. bis. $\mathrm{O}$ mesmo, soltando flatulências continuamente, não sabia <soltar uma flatulência> .

238. Um homem com mau hálito foi a um verdureiro e perguntou: "Atendente, tem figos secos?" Este, todavia, retirando-se: "Não, nem sequer fffffffiiiiiiiiiiigos fffffffffeeeeeenícios”.

239. Um jovem actor trágico era amado por duas mulheres, uma com mau hálito e outra com cheiro a suor. Uma disse: “Dá-me um beijo, amor!” E a outra: "Dá-me um abraço, amor!" 
Ele respondeu: "Oh, que desgraçado de mim! Estou dividido por dois males!”

240. Um homem com mau hálito estava sentado num teatro junto a um homem com cheiro a suor. Um jovem chegou e calhou sentar-se entre eles. Sentindo o odor daquele, voltou-se para o homem com mau hálito e perguntou: "Quem é que se descuidou?" Reconhecendo que o motivo era da boca dele, voltou-se para o outro, para conversar com ele. Mas, ao perceber que ele cheirava mal, levantou-se e saiu.

241. Um louco deu um traque enquanto estava deitado com um indivíduo surdo. Quando este último se apercebeu do cheiro e começou a queixar-se, ele comentou: "Vá lá, como é que tu poderias ter ouvido? Ainda assim, estás a fazer mofa de mim."

242. Um homem com cacostomia que olhava continuamente muitas vezes para o céu, fez uma oração. Ao olhar para baixo, Zeus diz: "Tem piedade! Também tens os deuses ctónicos!”

243. Ao ser convidado por um amigo para ir apanhar fruta, um homem guloso comeu um grande número de figos e de uvas. <...>

Resultado: nessa noite teve uma dor de barriga que lhe causou um sonho no qual ele viu o seu amigo sentado junto a uma figueira e a chamá-lo para comer figos. Mas, estando no cimo, ele aliviou-se, vertendo 
os excrementos, a partir do alto da figueira. Ora ele de facto defecou na cama.

Ao acordar e verificar o que tinha feito, lavou as roupas de cama e voltou a adormecer. Então prosseguiu com o mesmo sonho, excepto que desta vez ele olhou para o seu amigo na árvore e considerou: "Já estou a ver! Estás a ver se me fazes conspurcar a cama noutro sonho de merda! Mas desta vez não resultará. Vou defecar antes e trepar à árvore depois.” Então acordou e - encontrou outra bosta feita na cama!

\section{SOBRE MULHERES LIBERTINAS}

244. Um homem jovem disse à sua esposa impudente: "Esposa, o que é que vamos fazer? Comer ou fazer amor?"

"O que quiseres: não há pão."

245. Um jovem convidou duas velhas despudoradas e disse para os seus criados de casa: "Sirvam a uma delas uma taça de vinho e dêem uma queca a outra! E elas alertaram: "Não temos sede."

\section{A RESPEITO DE HOMENS MISÓGINOS}

246. Um misógino que estava no mercado anunciou: "Comprem a minha mulher livre de impostos!”

Então houve quem lhe perguntasse: "Como 
assim?" Ele esclareceu: "Para que as autoridades possam confiscá-la."

247. Um misógino estava a enterrar a sua falecida mulher.

"Quem é que ganhou o descanso eterno?", perguntou alguém.

"Eu, agora que me vi livre dela."

248. Um misógino muito doente estava desanimado, mas a sua esposa disse-lhe: "Se sofreres alguma coisa, juro que me enforco", ao que ele the retorquiu: "Isso anima-me se o fizeres mesmo estando eu vivo."

249. Um misógino tinha uma esposa que estava sempre a tagarelar e que era uma chata. Quando ela morreu, ele mandou levá-la até ao túmulo num escudo. Quando alguém viu e questionou o porquê, ele respondeu: "É que ela era combativa."

250. Um jovem, ao ser questionado se era a mulher dele que mandava ou se ele lhe obedecia em tudo, pavoneando-se ele afirmou: "Eu, sem dúvida, atemorizo a minha mulher! Se eu abro a boca ela evacua!"

251. Uma mulher tinha um escravo atrasado mental. Mas quando ela se apercebeu que ele possuía uma protuberância excepcionalmente grande, desenvolveu uma paixão por ele. Cobriu a cara com uma máscara para que ninguém a reconhecesse e levou-o para a cama. 
Mas nisto ele identificou de quem se tratava. Então chegou ao pé do senhor da casa e disse com uma risada: "Senhor, senhor! Dormi com a dançarina mascarada e a senhora estava lá dento!”

252. Havia um eunuco infeliz que praticou uma sedução.

253. Ao encontrar um médico, um idiota justificou-se: "Por favor desculpe-me e não se aborreça comigo por eu não ter estado doente."

254. Um idiota selou cuidadosamente a garrafa de um vinho antigo. Mas um escravo fez-lhe um furo e retirou-lhe um bocado.

O idiota não conseguia perceber porque é que o nível da garrafa tinha descido, uma vez que os selos estavam intactos.

Então um outro sugeriu: "Vê se estarão a roubar pelo fundo.”

Ao que ele disse: "Não sejas estúpido! Não consegues ver que é a metade de cima que está a faltar e não a do fundo?”

255. Ao ser informado de que os corvos viviam duzentos anos e até mais, um idiota comprou um para testá-lo.

256. Um idiota estava num barco quando se acercou uma tempestade. Ao ver os passageiros a segurar 
em coisas para se salvar, ele agarrou-se a uma das âncoras.

257. Tendo acabado de sepultar o seu filho, um idiota encontrou o professor dele e disse-lhe: "O rapaz compareceu?" Mas ele disse: "Não." E então o idiota: "Ora desculpe, mestre, ele morreu."

258. Tendo um mestre idiota de ginástica juvenil ouvido que o seu aluno estava doente; depois, que estava com febre, e tendo ouvido mais tarde, pelo seu pai, que ele tinha morrido, referiu: "Se continuarem a dar-lhe todas essas desculpas para ele faltar, ele nunca terá hipótese de aprender.”

259. Um idiota tinha comprado um bocado de carne e estava a levá-lo para casa, quando um falcão desceu e lho tirou das mãos. Ele disse: "Que eu me torne como tu, se eu não fizer o mesmo a alguém!"

$$
\text { 260. Igual a } 151 \text { bis. }^{27}
$$

\section{A PROPÓSITO DE GLUTÓES}

261. Um magistrado glutão ordenou a sua assembleia para se reunir voltada para uma padaria.

262. Tendo um engraçadinho viajado e contraído

\footnotetext{
${ }^{27}$ Idem est ac 151 bis.
} 
um edema, ao regressar, a esposa perguntou-lhe se ele lhe tinha trazido alguma coisa. "Ora, para ti, nada, referiu ele, mas para as minhas coxas, uma almofada."

263. Eu fiquei com a tua mulher para nada, zombou alguém com um engraçadinho.

Mas ele retorquiu: "Porém eu tenho necessidade de aguentar esse mal. E tu, tens alguma necessidade?"

264. Um engraçadinho estava a ser julgado por um juiz. Mas, como este tivesse dormitado, ele gritou: "Apelo!" E aquele questionou: "A propósito de quê?” E o outro: "A ti, para estares acordado."

265. Perguntou-se a um idiota quantas medidas podia uma ânfora comportar? "Referes-te a vinho ou a água?" 



\section{BibLIOGRAFia}

A. Eberhard, ed (1869), Philogelos Hieroclis et Philagrii facetiae. Berolini, Ebeling \& Plahn.

A. Körte (1903), "Hermann Reichs Mimus», Neue Jahrbücher für das klassische Altertum 11 537-549.

A. Mitchell (2009), Greek Vase-Painting and the Origins of Visual Humour. Cambridge/New York, Cambridge University Press.

A. Rapp (1951a), “A Greek 'Joe Miller”, CJ 46.6 286-290, 318.

(1951b), The origins of wit and humor. New York, Dutton.

A. Thierfelder (1968a), Philogelos der Lachfreund von Hierokles und Philagrios. Griechisch und deutsch mit Einleitungen und Kommentar. München, Heimeran.

-(1968b), "Philogelos”, RESuppl. 11 1062-1068.

B. Baldwin (1986), "John Tzetzes and the Philogelos". Byzantion 56 339-341.

B. Baldwin, com. (1983), The Philogelos or LaughterLover. Amsterdam, Brill Academic Publishers.

B. Perry (1943), "On the Manuscripts of the Philogelos" in Classical Studies in Honor of William Abbott Odfather. Presented by a Committee of His Former Students and Colleagues, Urbana. Urbana, 
University of Illinois Press 157-166.

C. Bubb (1920), The Jests of Hierocles and Philagrius. Cleveland, The Rowfant Club 5-14.

C. Bursian (1870), “Zu der Anekdotensammlung des Hierokles und Philagrios", Neue Jahrbücher für Philologie und Paedagogik 101740.

C. Mundy (1965), "Philogelos, the Nesnas and

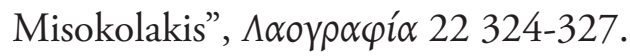

D. Tamilia (1900), "De nonnullis Hieroclis et Philagrii facetiis" in Cod. Vat. Gr. 112, SIFC 8 89-90.

E. Kurtz (1887), "Zum Philogelos des Hierokles», Blätter für das Bayerische Gymnasialschulwesen 23 368-370.

E. Mehler (1878), "Ad Sam. Adr. Naber epistula critica", Mnemosyne 6 387-412.

E. Orso (1979), Modern Greek Humor: a collection of jokes and ribald tales. Bloomington/London, Indiana University Press.

E. Saint-Denis (1965), Essais sur le rire et le sourire des Latins. Paris, Les Belles Lettres.

E. Sikes (1940), "The Humour of Homer", CR 54.3 121-127.

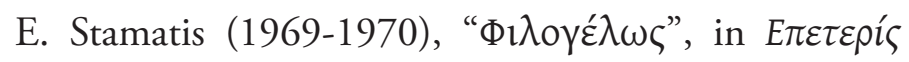

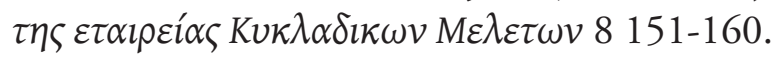

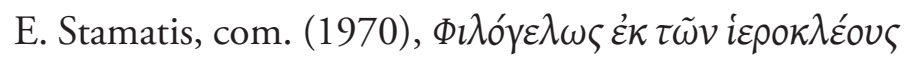




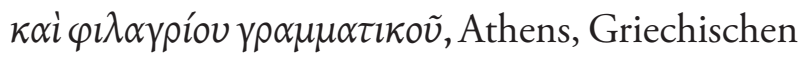
Kulturministerium.

E. Wüst (1938), “Philistion”, RE 19.2 2402-2405.

F. Brecht (1930), Motiv und Typengeschichte des griechischen Spottepigramms. Leipzig, Dieterich.

F. Cornford (2011), The Origin of Attic Comedy. Cambridge, Cambridge University Press.

F. Hertlein (1877), “Zu griechischen Prosaikern”, Hermes 12 182-188.

F. Liebrecht (1870), “Zum Philogelos des Hierokles”, Philologus 30235.

G. Constable - A. Kazdan (1982), People and Power in Byzantium. An Introduction to Modern Byzantine Studies. Washington, Dumbarton Oaks.

G. Gerhard (1938), "Griechische Papyri. Urkunden und Literarische Texte aus der Papyrus-Sammlung der Universitätsbibliothek Heidelberg" in Herausgegeben und erklärt. Heidelberg, Carl Winter Universitätsverlag 38-40.

G. Hendrickson (1927), "Satura tota nostra est", CPh 22.1 42-60.

G. Legman (1968-1975), The Rationale of the Dirty Joke: an analysis of sexual humour, vol.1-2. New York, Grove Press.

G. Löwe (1981), Philogelos oder Lachen in der Antike 
von Hierokles und Philagrios. Hanau, Werner Dausien Verlag.

G. Monaco (1966), Paragoni burleschi degli antichi. Palermo, Palumbo.

G. Morgan (1981), “Philogelos 216”, JHS 101 140-141.

G. Ritter (1955), Studien Zur Sprache Des Philogelos. Leemann, Universität Basel.

H. Arnim - W. Schubart (1906), Hierokles Ethische Elementarlehre, papyrus 9780. Berlin, Weidmannsche Buchhlandlung.

H. Parker (2011), "Toward a Definition of Popular Culture", H\&T 50 147-170.

H. Reich (1903), "Philistions Philogelos" in Der Mimus. Ein litterar-entwicklungsgeschichtlicher Versuch, vol. 1. Berlin, Weidmannsche Bychhandlung 454-475.

H. Thiel (1972), "Philogelos 237”, Hermes 100509.

J. Boissonade (1848), Hierokles kai Philagrios. G. Pachymeris declamationes XIII quarum XII ineditae, Hieroclis et Philagrii grammaticorum $\varphi \imath \lambda o ́ \gamma \varepsilon \lambda \omega \varsigma$ longe maximam partem ineditus. Paris, Dumont et Leleux.

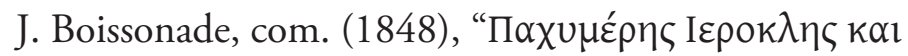

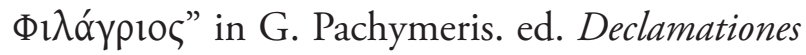
XII quarum XI inedite Hieroclis et Philagrii

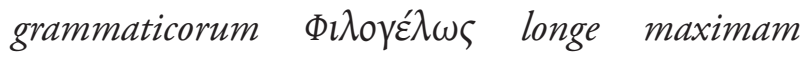


partem ineditus curante. Parisiis, N. Yemeniz (Byzantio) 263-324.

J. Bremmer - H. Roodenburg, eds (1997), A Cultural History of Humour from Antiquity to the Present Day. Cambridge, Polity Press.

J. Edmonds (1957), The Fragments of Attic Comedy, vol. 3A. Leiden, Brill Archive.

J. Holt (2008), Stop Me If You've Heard This: A History and Philosophy of Jokes. New York, WW Norton 8-11.

J. Horovitz (1905), "Ein syrischer Philogelos" in Spuren griechischer Mimen im Orient. Mit einem Anhang über das egyptische Schattenspiel von Friedrich Kern. Berlin, Mayer \& Müller 55-76.

J. Rougé (1987), "Le Philogelôs et la navigation”, JS 3-12.

J. Toner (2009), Popular Culture in Ancient Rome. Cambridge, Polity.

J. Wilkinson — S. Birch, eds (1878), The manners and customs of the ancient Egyptians, London, J. Murray.

J. Winkler (1991), Auctor and actor: a narratological reading of Apuleius' Golden Ass. Los Angeles, University of California Press 160-163.

K. Praechter (1901), Hierokles der Stoiker. Leipzig, Dieterich. 
L. Floridi (2012), “Greek Skoptic Epigram and 'Popular' Literature: Anth.Gr. XI and the Philogelos", GRBS 52 632-660.

L. Robert (1969), "Les epigrammes satiriques de Lucillius sur les athletes: Parodie et realites", Entretiens sur l'Antiquité Classique 14 181-291.

L. Welborn (2005), Paul, the Fool of Christ: A Study of 1 Corinthians 1-4 in the Comic-Philosophic Tradition. London, Continuum International Publishing Group.

M. Andreassi (2004), Le facezie del Philogelos. Barzellette antiche e umorismo moderno. Lecce, Pensa Multimedia Editore.

M. Andreassi (2006a), "Citazioni teatrali nelle facezie del Philogelos" in O. Vox, ed. Memoria di testi teatrali antichi. Lecce, Pensa Multimedia Editore 11-32.

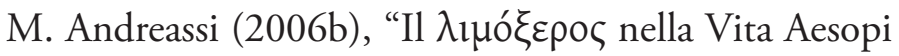
e nel Philogelos”, ZPE 158 95-103.

M. Beard (2013), Confronting the Classics: Traditions, Adventures and Innovations. London, Profile Books.

M. Douglas (1999), "Jokes" in Implicit Meanings: selected essays in anthropology. London/New York, Routledge 146-164.

M. Haupt (1871), "Varia”, Hermes 5 21-47. 
M. Schmidt (1871), "Verbesserungsvorschläge zu schwierigen Stellen griechischer Schriftsteller", RhM 26 161-234.

O. Schütze, ed (1997), Metzler Lexicon antiker Autoren. Stuttgart/Weimar, Metzler.

P. Horst (1978), “Is Wittiness Unchristian?” T. Baarda et al. eds, Miscellanea Neotestamentica, vol. 2. Leiden, Brill 163-176.

P. Needham (1709), Hieroclis Philosophi Alexandrini Commentarius in Aurea Carmina, de Providentia Et Fato. Cambridge, A. \& J. Churchill.

P. Rousseau, ed. (2009), A Companion to Late Antiquity. Malden/Oxford, Wiley-Blackwell.

Q. Cataudella (1970), "Note critiche al testo del 'Philogelos', RCCM 12 349-356.

Q. Cataudella (1971), La facezia in Grecia e a Roma. Saggio introduttivo e ampia antologia. Firenze, Le Monnier.

R. Dawe (1997), “Textual Observations on Philogelos", GRBS 38.3 307-328.

R. Dawe, ed (2000), Philogelos. Monachi et Lipsiae, Bibliotheca Scriptorum Graecorum et Romanorum Teubneriana.

R. Kassel (1956), "Reste eines hellenistischen Spaßmacherbuches auf einem Papyrus?", RhM 99 242-245. 
R. Starr (1990), "The Used-Book Trade in the Roman World", Phoenix 44.2 148-157.

R. Syme (1983), Historia Augusta papers. Oxford, Clarendon Press.

S. Ballou (1914), The manuscript tradition of the Historia augusta. Leipzig, B.G. Teubner.

S. Freud (1905), Jokes and their Relation to the Unconscious. London, The Hogarth Press.

S. Johnson (1741), "The Jests of Hierocles", Gentleman's Magazine 11 477-479.

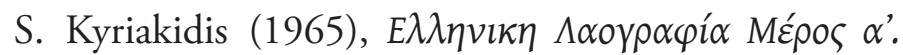

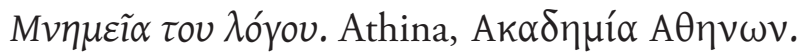

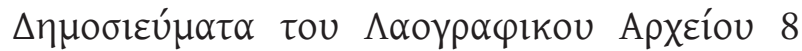
236-239.

T. Korsch (1877/1878), "Emendationes”, Nordisk Tidskrift for Filologi 3 131-136.

V. Propp (1992), Comicidade e Riso, São Paulo, Ática 79-83.

W. Christ Schmid - O. Stählin (1924), Geschichte der griechischen Litteratur, vol. 2. München, Francke 1049.

W. Dominik, ed. (2002), Words and Ideas. Wauconda, Bolchazy-Carducci Publishers.

W. Gemoll (1924), Das Apophthegma. Literarhistorische Studien. Wien/Leipzig, Freytag. 
W. Hansen (1998), Anthology of Ancient Greek Popular Literature. Bloomington/Indiana, Indiana University Press.

W. Hansen (2001), “The Seer and the Computer: On Philogelos and Modern Jokes”, CB 77 87-102.

W. Heraeus (1930), "Drei Fragmente eines Grammatikers Ovidius Naso?”, RhM79391-405.

W. Ribeiro Jr. (2006), "O Médico como Objecto de Riso na Antologia Palatina”, Classica 19.2 224-233.

W. Smith (1580), Dictionary of Greek and Roman Biography and Mythology, vol. 2. Boston, C. Little and J. Brown. 



\section{ÍNDICE TEMÁTICO}

Abdera: 17; 47; 48; 49; 50

Advogado: 18; 35; 54

Afrodite: 72

Ágora: 52

Água: 23; 34; 35; 37; 43; 48; 49; $58 ; 62 ; 79$

Alcoólicos: 17; 71; 72

Alexandria: $11 ; 11$, n.3; 13; 13, n.9; $14 ; 59$

Alface(s): 26, 34

Aluno: 52; 78

Amigo: 24; 25; 26; 27; 31; 32; $37 ; 38 ; 42 ; 43 ; 44 ; 57 ; 74$; 75

Amor: 73; 75

Arado: 45; 51

Árbitro: 53

Artéria: 70

Árvore: 27; 39; 70; 75

Astrologia (astrólogo): 18; 63

Atenas: 34

Atleta: 36

Augusto: 12; 16

Avareza (avarento): 17; 40; 46

Aveia: 70

Aves: 31; 36; 50
Avós: 28; 33

Azeite (azeitona): 46; 47; 52

Banhos: 17; 27; 46; 51; 58; uide Termas

Barbeiro: 18; 35; 54; 58; 65

Barcos: 17; 29; 37; 40; 42; 43;

77

Beijo: 73

Bílis: 62

Boca: $62 ; 73 ; 74 ; 76$

Boxe (lutador de): 59; 67; 68; 69

Burro(s): 24; 47; 50; 58

Cabeça: 26; 32; 35; 37; 41; 42; $46 ; 47 ; 62 ; 63 ; 67 ; 72$

Caçador: 67

Caixão (-ôes): 34; 44

Calçado (sapato): 33; 62 uide sapateiro

Calças: 13; 37

Calvície (careca): 35

Cão (-ães): 28; 67

Capitão: 34; 40; 51; 53; 64

Carro (carroça, carroceiro, cocheiro): $45 ; 50 ; 52 ; 56$

Casa: $26 ; 27 ; 31 ; 34 ; 41 ; 42 ; 46$; 49; 56; 57; 59; 64; 68; 69; 
$75 ; 77 ; 78$

Casamento: 38; 69

Cavalo de Tróia: 54

Cavalos: 23; 25; 29; 30; 38; 43; $53 ; 56$

Cebola: 49; 53

Cego (cegueira): 14; 36; 65

Centurião (-ões): 52

Cobardia (cobardes): 17; 43; 67; 68; 69

Corredores (atletas): 49; 53

Corvo: 77

Coxa: 79

Coxo: 65

Criança: $31 ; 35$

Cumas: $17 ; 56 ; 57 ; 58 ; 59 ; 60$; $61 ; 62$

Dançarina: 77

Demagogo: 61

Denário: 45; 50; 65; 68; 70; 71

Dentes (dentição): 23; 31; 56; 57

Diomedes: 54

Dioniso: 36

Doença (doentes): 12; 17; 18; $24 ; 28 ; 30 ; 31 ; 38 ; 39 ; 40$; 48; 49; 52; 76; 77; 78; uide doença em particular

Dracma(s): 30; 40; 52

Dracôntides: 59

Edema: 47; 48; 49; 79

Éforos: 61

Enforcamento: 47; 62; 76

Engraçadinhos: 17; 53; 54; 55;
$78 ; 79$

Escada: 34; 43; 64

Escravo(s): 17; 24; 25; 27; 28; 29; 46; 64; 76; 77

Escribónia: 14; 38

Esmirna: 52

Esposa: 28; 38; 40; 48; 54; 57; $71 ; 72 ; 75 ; 76 ; 79$

Estúpido (uide idiota, papalvo, parvo): 17; 28; 35; 65; 66; $67 ; 77$

Eunuco: 47; 48; 77

Facécia(s). Facetia (-ae): 9; 9, n. $1 ; 10 ; 11$, n. $3 ; 12 ; 13 ; 14$, n. $9 ; 16$

Falcão: 78

Febre: 28; 30; 40; 60; 78

Feijão: 53

Fenício: 73

Fígado(s): 45; 51; 62; 64

Figo(s): 58; 61; 70; 73; 74

Filhos: 29; 31; 35; 37; 38; 39; $43 ; 44 ; 52 ; 73 ; 78$

Flatulência (traque): 73; 74

Formigueiro: 59

Funeral: 31; 52; 56

Gémeos: 45

Ginásio (ginástica): 47; 78

Gladiador: 14; 41

Glutão: 17; 69; 70; 71; 78

Governador: 18; 50; 66

Hades: 47

Hálito: 17; 72; 73; 74

Hera: 72 
Herança: 52

Horóscopo: 14; 63; 66

Idiota: $17 ; 23 ; 24 ; 25 ; 27 ; 28$; 29; 30; 31; 32; 33; 34; 35; 36; 37; 38; 39; 40; 41; 42; $43 ; 44 ; 45 ; 51 ; 60 ; 77 ; 78$; 79 uide imbecil, papalvo, parvo, pateta, sandeu, xexé

Imbecil: 25; 27; 30; 37; 40; 41; 42; 44 uide idiota, papalvo, parvo, pateta, sandeu, xexé

Indigestão: 43

Insalubridade: $28 ; 38$

Jantar: 27; 29; 34; 36; 42; 44; 46 Jardim (jardineiro): $58 ; 70$

Jogo (jogar): 13; 29; 36; 40; 63

Juiz (juízes): 18; 69; 79

Lá: 45; 51

Leite: $45 ; 51$

Língua: 53

Livros: 14; 24; 26; 32; 33; 35; 41

Magistrado: 36; 61; 66; 78

Mal-humorados: 17; 62; 63; 64

Marcos: 32; 36; 51

Médico (doutor): 12; 18; 23; 24; 28; 40; 46; 47; 52; 53; 55; $60 ; 61 ; 62 ; 63 ; 70 ; 73 ; 77$

Mel: 59; 63

Melisso: 16

Menelau: 54

Mentiroso: 45

Milhas: 36; 51

Minoides Minas: 9, n.1

Misantropo: 63

Mula: 45; 50
Mulher: 44; 48; 73; 75; 76; 79

Músico: 16; 53; 54

Nadar: 23; 29; 44; 58; 66; 68; $72 ; 79$

Namorada: 46

Orador: 50

Ovelha(s): 33; 45; 46; 51; 58

Padaria: 69; 78

Pais: $18 ; 23 ; 25 ; 28 ; 30 ; 31 ; 32$; $33 ; 34 ; 35 ; 37 ; 38 ; 41 ; 43$; 49; 52; 55; 56; 58; 59; 66; $68 ; 72 ; 76 ; 78$

Pão: $70 ; 71 ; 75$

Papalvo: 32; 36 uide idiota, imbecil, parvo, pateta, sandeu, xexé

Pardal: 50

Parricídas: 25; 55

Parvo: 17; 26; 32 uide idiota, imbecil, papalvo, pateta, sandeu, xexé

Pateta (apatetado): 24 uide idiota, imbecil, papalvo, parvo, sandeu, xexé

Pescador: 51

Porco: 42; 45; 51; 54

Prefeito: 66

Preguiçosos: 17; 68

Príamo: 65

Professor: 16; 18; 36; 39; 42; 53; $65 ; 70 ; 78$

Profeta (Profecias): 14; 66; 67

Rapaz(es): 25; 30; 39; 43; 63; $66 ; 68 ; 78$

Ratos: 24; 60 
Recipiente (vaso, garrafa, pote): Túmulo (sepulcro): 28; 38; 76

27; 32; 47; 49; 77

Reno: $14 ; 40$

Rim (rins): 51

Rodes: 14; 50; 64

Roma (romanos): 10, n.2; 13; $14 ; 16 ; 18 ; 36 ; 52$

Roupas: 26; 30; 38; 56; 75

Sábio: 51

Sacerdotes: 39; 61

Sacrifícios: 61

Sandeu: 26; 70 uide idiota, imbecil, papalvo, parvo, pateta, xexé

Sapateiro: 62

Senhora: 65; 72; 77

Serapeum - 13

Sicília: 14; 64

Sidónios: 17; 50; 51; 52

Sonhos: 24; 45; 49; 74; 75

Sovina: 46

Suor (transpirar): 63; 73; 74

Surdez: $72 ; 74$

Talhantes: 61

Teatro: 74

Tempestade: 28; 40; 77

Termas: 27; 35; 47; 48; 51; 54; $55 ; 58$

Testamento: 28; 29; 42; 46; 52

Testemunhas: 54

Timoneiro: 42; 53

Trabeata: 16; 17

Transpirar: uide suar.

Tribunal: 47; 54
Úbere: $45 ; 51$

Ulisses: 54

Urina (-r): 48; 69

Urso(s): 67; 69; 72

Usurário: 57

Útero: 45

Uvas: $32 ; 74$

Úvula: $24 ; 73$

Veia: 70

Viagem (viajar): 14; 17; 25; 26; $28 ; 35 ; 37 ; 40 ; 41 ; 42 ; 45$; $50 ; 51 ; 58 ; 62 ; 66 ; 78$

Vinha: 36; 72

Vinho: 28; 40; 52; 71; 72; 75; $77 ; 79$

Xexé: 24; 35 uide idiota, imbecil, papalvo, parvo, pateta, sandeu

Zeus: $72 ; 74$ 


\section{Volumes publicados na ColecÇáo Autores Gregos e LATINos - SérIe TeXtos GREgos}

1. Delfim F. Leão e Maria do Céu Fialho: Plutarco. Vidas Paralelas - Teseu e Rómulo. Traduçáo do grego, introdução e notas (Coimbra, CECH, 2008).

2. Delfim F. Leão: Plutarco. Obras Morais - O banquete dos Sete Sábios. Tradução do grego, introdução e notas (Coimbra, CECH, 2008).

3. Ana Elias Pinheiro: Xenofonte. Banquete, Apologia de Sócrates. Tradução do grego, introdução e notas (Coimbra, CECH, 2008).

4. Carlos de Jesus, José Luís Brandão, Martinho Soares, Rodolfo Lopes: Plutarco. Obras Morais - No Banquete $I$ - Livros I-IV. Tradução do grego, introdução e notas. Coordenação de José Ribeiro Ferreira (Coimbra, CECH, 2008).

5. Ália Rodrigues, Ana Elias Pinheiro, Ândrea Seiça, Carlos de Jesus, José Ribeiro Ferreira: Plutarco. Obras Morais - No Banquete II - Livros V-IX. Tradução do grego, introdução e notas. Coordenação de José Ribeiro Ferreira (Coimbra, CECH, 2008).

6. Joaquim Pinheiro: Plutarco. Obras Morais - Da Educação das Crianças. Tradução do grego, introdução e notas (Coimbra, CECH, 2008).

7. Ana Elias Pinheiro: Xenofonte. Memoráveis. Tradução do grego, introdução e notas (Coimbra, $\mathrm{CECH}, 2009)$. 
8. Carlos de Jesus: Plutarco. Obras Morais - Diálogo sobre o Amor, Relatos de Amor. Tradução do grego, introdução e notas (Coimbra, CECH, 2009).

9. Ana Maria Guedes Ferreira e Ália Rosa Conceição Rodrigues: Plutarco. Vidas Paralelas - Péricles e Fábio Máximo. Tradução do grego, introdução e notas (Coimbra, CECH, 2010).

10. Paula Barata Dias: Plutarco. Obras Morais - Como Distinguir um Adulador de um Amigo, Como Retirar Benefício dos Inimigos, Acerca do Número Excessivo de Amigos. Tradução do grego, introdução e notas (Coimbra, CECH, 2010).

11. Bernardo Mota: Plutarco. Obras Morais - Sobre a Face Visivel no Orbe da Lua. Tradução do grego, introdução e notas (Coimbra, CECH, 2010).

12. J. A. Segurado e Campos: Licurgo. Oração Contra Leócrates. Tradução do grego, introdução e notas (Coimbra, CECH /CEC, 2010).

13. Carmen Soares e Roosevelt Rocha: Plutarco. Obras Morais - Sobre o Afecto aos Filhos, Sobre a Música. Tradução do grego, introdução e notas (Coimbra, $\mathrm{CECH}, 2010)$.

14. José Luís Lopes Brandão: Plutarco. Vidas de Galba e Otão. Tradução do grego, introdução e notas (Coimbra, CECH, 2010). 
15. Marta Várzeas: Plutarco. Vidas de Demóstenes e Cícero. Tradução do grego, introdução e notas (Coimbra, $\mathrm{CECH}, 2010)$.

16. Maria do Céu Fialho e Nuno Simóes Rodrigues: Plutarco. Vidas de Alcibiades e Coriolano. Tradução do grego, introdução e notas (Coimbra, CECH, 2010).

17. Glória Onelley e Ana Lúcia Curado: Apolodoro. Contra Neera. [Demóstenes] 59. Tradução do grego, introdução e notas (Coimbra, CECH, 2011).

18. Rodolfo Lopes: Platão. Timeu-Crítias. Tradução do grego, introdução e notas (Coimbra, CECH, 2011).

19. Pedro Ribeiro Martins: Pseudo-Xenofonte. A Constituição dos Atenienses. Tradução do grego, introdução, notas e índices (Coimbra, CECH, 2011).

20. Delfim F. Leão e José Luís L. Brandão: Plutarco. Vidas de Sólon e Publícola. Tradução do grego, introdução, notas e índices (Coimbra, CECH, 2012).

21. Custódio Magueijo: Luciano de Samósata I. Tradução do grego, introdução e notas (Coimbra, CECH/IUC, 2012).

22. Custódio Magueijo: Luciano de Samósata II. Tradução do grego, introdução e notas (Coimbra, CECH/IUC, 2012).

23. Custódio Magueijo: Luciano de Samósata III. Tradução do grego, introdução e notas (Coimbra, CECH/IUC, 2012). 
24. Custódio Magueijo: Luciano de Samósata IV. Tradução do grego, introdução e notas (Coimbra, CECH/IUC, 2013).

25. Custódio Magueijo: Luciano de Samósata $V$. Tradução do grego, introdução e notas (Coimbra, CECH/IUC, 2013).

26. Custódio Magueijo: Luciano de Samósata VI. Tradução do grego, introdução e notas (Coimbra, CECH/IUC, 2013).

27. Custódio Magueijo: Luciano de Samósata VII. Tradução do grego, introdução e notas (Coimbra, CECH/IUC, 2013).

28. Custódio Magueijo: Luciano de Samósata VIII. Tradução do grego, introdução e notas (Coimbra, CECH/IUC, 2013).

29. Custódio Magueijo: Luciano de Samósata IX. Tradução do grego, introdução e notas (Coimbra, CECH/IUC, 2013).

30. Reina Marisol Troca Pereira: Hiérocles e Filágrio. Philogelos ( $O$ Gracejador). Tradução do grego, introdução e notas (Coimbra, CECH/IUC, 2013). 
IMPRESSÃO:

Artipol - Artes tipográficas, Lda.

Zona industrial de Mourisca do Vouga, Apartado 3051 3754-901 ÁguedA 
OBRA PUBLICADA

COM A COORDENAÇÁO

CIENTÍFICA

0
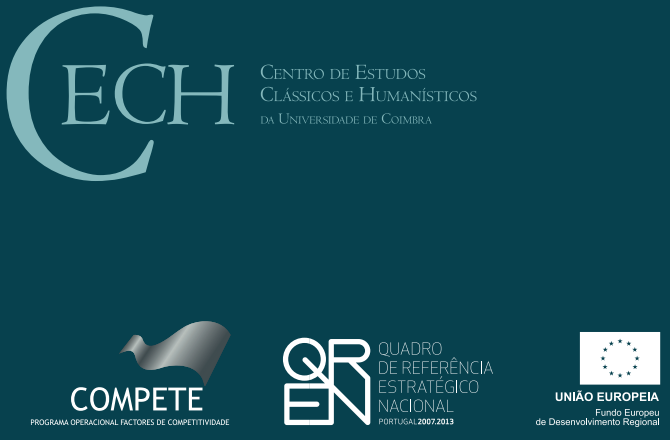